\section{Energy Sector Market Analysis}

\section{Sponsored by the Weatherization and} Intergovernmental Program (WIP) at DOE

D. Arent, R. Benioff, G. Mosey, L. Bird, J. Brown, E. Brown, L. Vimmerstedt, J. Aabakken, and K. Parks National Renewable Energy Laboratory

M. Lapsa, S. Davis, M. Olszewski, D. Cox, K. McElhaney, and S. Hadley

Oak Ridge National Laboratory

D. Hostick, A. Nicholls, S. McDonald, and B. Holloman

Pacific Northwest National Laboratory
Technical Report NREL/TP-620-40541

October 2006 


\section{Energy Sector Market Analysis}

Sponsored by the Weatherization and Intergovernmental Program (WIP) at DOE

D. Arent, R. Benioff, G. Mosey, L. Bird, J. Brown, E. Brown, L. Vimmerstedt, J. Aabakken, and K. Parks

National Renewable Energy Laboratory

M. Lapsa, S. Davis, M. Olszewski, D. Cox, K. McElhaney, and S. Hadley

Oak Ridge National Laboratory

D. Hostick, A. Nicholls, S. McDonald, and

B. Holloman

Pacific Northwest National Laboratory

Prepared under Task No. IGST.5000

National Renewable Energy Laboratory

1617 Cole Boulevard, Golden, Colorado 80401-3393

303-275-3000 • www.nrel.gov

Operated for the U.S. Department of Energy

Office of Energy Efficiency and Renewable Energy

by Midwest Research Institute • Battelle

Contract No. DE-AC36-99-G010337
Technical Report NREL/TP-620-40541

October 2006

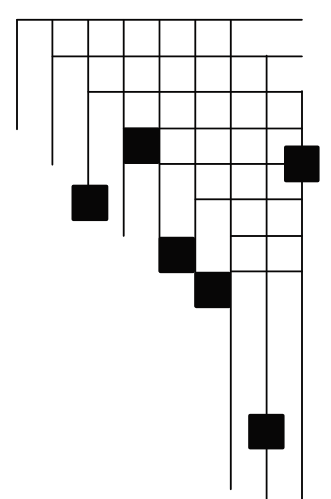




\section{NOTICE}

This report was prepared as an account of work sponsored by an agency of the United States government. Neither the United States government nor any agency thereof, nor any of their employees, makes any warranty, express or implied, or assumes any legal liability or responsibility for the accuracy, completeness, or usefulness of any information, apparatus, product, or process disclosed, or represents that its use would not infringe privately owned rights. Reference herein to any specific commercial product, process, or service by trade name, trademark, manufacturer, or otherwise does not necessarily constitute or imply its endorsement, recommendation, or favoring by the United States government or any agency thereof. The views and opinions of authors expressed herein do not necessarily state or reflect those of the United States government or any agency thereof.

Available electronically at http://www.osti.gov/bridge

Available for a processing fee to U.S. Department of Energy and its contractors, in paper, from:

U.S. Department of Energy

Office of Scientific and Technical Information

P.O. Box 62

Oak Ridge, TN 37831-0062

phone: 865.576 .8401

fax: 865.576 .5728

email: mailto:reports@adonis.osti.gov

Available for sale to the public, in paper, from:

U.S. Department of Commerce

National Technical Information Service

5285 Port Royal Road

Springfield, VA 22161

phone: 800.553.6847

fax: 703.605.6900

email: orders@ntis.fedworld.gov

online ordering: http://www.ntis.gov/ordering.htm 


\section{TABLE OF CONTENTS}

Executive Summary ........................................................................................................................1

Cross-Sector Analytical Approach .............................................................................2

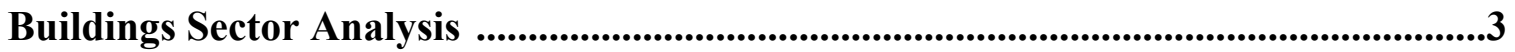

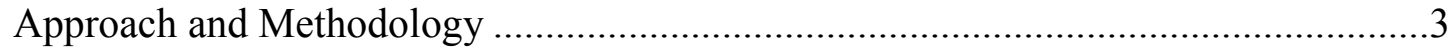

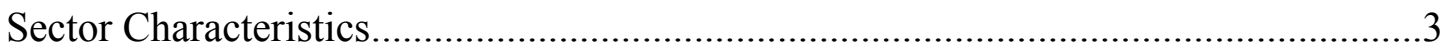

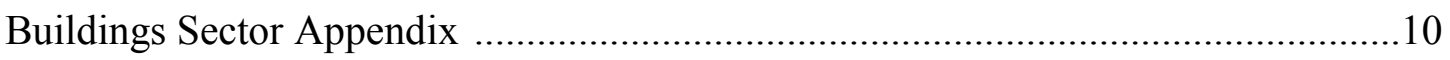

Clean-Energy Sector Analysis .............................................................................................17

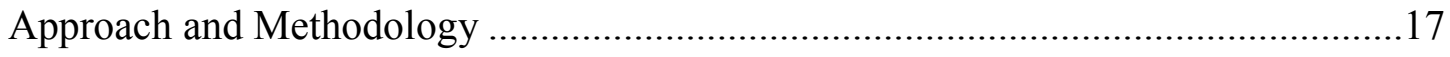

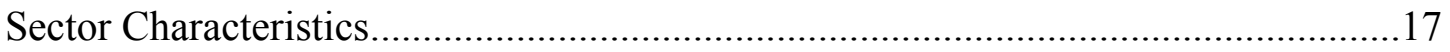

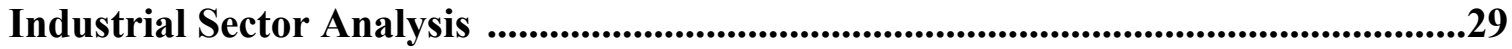

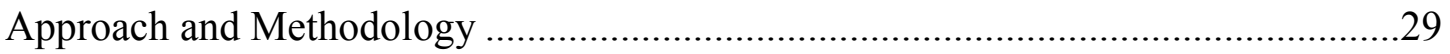

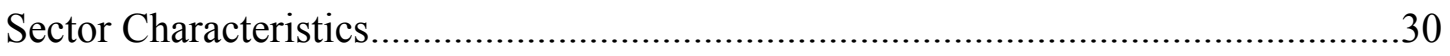

Transportation Sector Analysis .........................................................................36

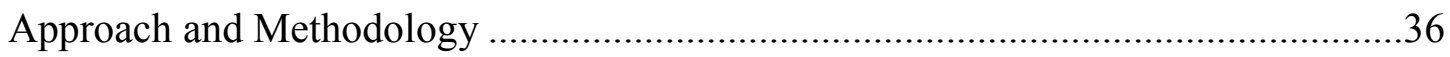

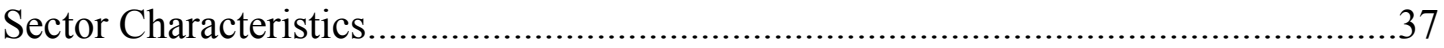




\section{EXECUTIVE SUMMARY}

This paper presents the results of energy market analysis sponsored by the Department of Energy's (DOE) Weatherization and Intergovernmental Program (WIP) within the Office of Energy Efficiency and Renewable Energy (EERE). The analysis was conducted by a team of DOE laboratory experts from the National Renewable Energy Laboratory (NREL), Oak Ridge National Laboratory (ORNL), and Pacific Northwest National Laboratory (PNNL), with additional input from Lawrence Berkeley National Laboratory (LBNL). The analysis was structured to identify those markets and niches where government can create the biggest impact by informing management decisions in the private and public sectors. The analysis identifies those markets and niches where opportunities exist for increasing energy efficiency and renewable energy use.

DOE's Weatherization and Intergovernmental Program provides tools, information, and technical and financial assistance to help inform decisions by states, communities, tribal authorities, businesses, manufacturers, consumers, and international partners on the use of energy efficiency and renewable energy technologies and policies. This analysis took a fresh look at key decisions that are driving the use of renewable energy and energy efficiency in U.S. buildings, electricity, industrial, and transportation markets. For these markets, the analysis identified opportunities to increase the use of renewable energy and energy efficiency technologies and practices.

The analysis attempted to answer the following questions:

- What are the current markets that WIP programs are addressing and what impacts is WIP having on these markets?

- What are the markets and segments within each market that hold the most potential for increased RE and EE deployment?

- What are the major barriers for each of the markets and segments?

- Who are the key customers and decision makers in each market and market segment, and what needs do they have for information or assistance.

- Who are the other key actors in each market and market segment, what activities are they pursuing, and what opportunities exist for government to leverage resources and capabilities with these players?

A common structure and format for the sectoral analyses was developed and performed for each of the target sectors: buildings, clean energy, industry, and transportation. Data were compiled and developed from existing information sources, including:

- Total energy use in the sector

- Energy use by major groups of energy users

- Current levels of technology penetration and energy-savings technical potential

- Market drivers and barriers

- Key market actors and stakeholders

- Investments in the sector

Methodologies, assumptions, and detailed results for each sector are presented in the body of this report. 


\section{CROSS-SECTOR ANALYTICAL APPROACH}

Analysis Team

The analytic team included:

Cross-Sector Analysis:

Douglas J. Arent, NREL

Ron Benioff, NREL

\section{Buildings:}

Donna Hostick, PNNL

Andrew Nicholls, PNNL

Sean McDonald, PNNL

Brad Hollomon, PNNL

John Brown, NREL

Transportation:

Gail Mosey, NREL

Elizabeth Brown, NREL

Laura Vimmerstedt, NREL

Jørn Aabakken, NREL

Melissa Lapsa, ORNL

Stacy Davis, ORNL

Clean Energy:

Lori Bird, NREL

Elizabeth Brown, NREL

Keith Parks, NREL

Stan Hadley, ORNL

Melissa Lapsa, ORNL

Industrial:

Mitch Olszewski, ORNL

Karen McElhaney, ORNL

Daryl Cox, ORNL 


\section{Buildings Sector Analysis}

\section{Approach and Methodology}

The buildings sector analysis was prepared using readily available sources, including Energy Information Administration (EIA) and other Department of Energy (DOE) data, Weatherization and Intergovernmental Program (WIP) project Web sites, and other reports prepared on energy efficiency and the buildings industry. More detailed information is contained in an appendix to this analysis.

\section{Sector Characteristics}

\section{Baseline Market Assessment}

Building-related energy use was almost 40.3 quadrillion Btu ${ }^{1}$ (QBtu) in 2002, or approximately $40 \%$ of the total primary energy use in the United States. Of that, approximately $52 \%$ is consumed by the residential sector; ${ }^{2} 43 \%$ by the commercial sector; ${ }^{3}$ and $5 \%$ by the industrial sector ${ }^{4}$ for non-process-related energy use associated with building energy services (e.g., lighting, HVAC). Of the total, almost $50 \%$ is due to electricity-related losses. ${ }^{5}$ Figure 1 illustrates the current and projected primary energy consumption for the residential and commercial sectors.

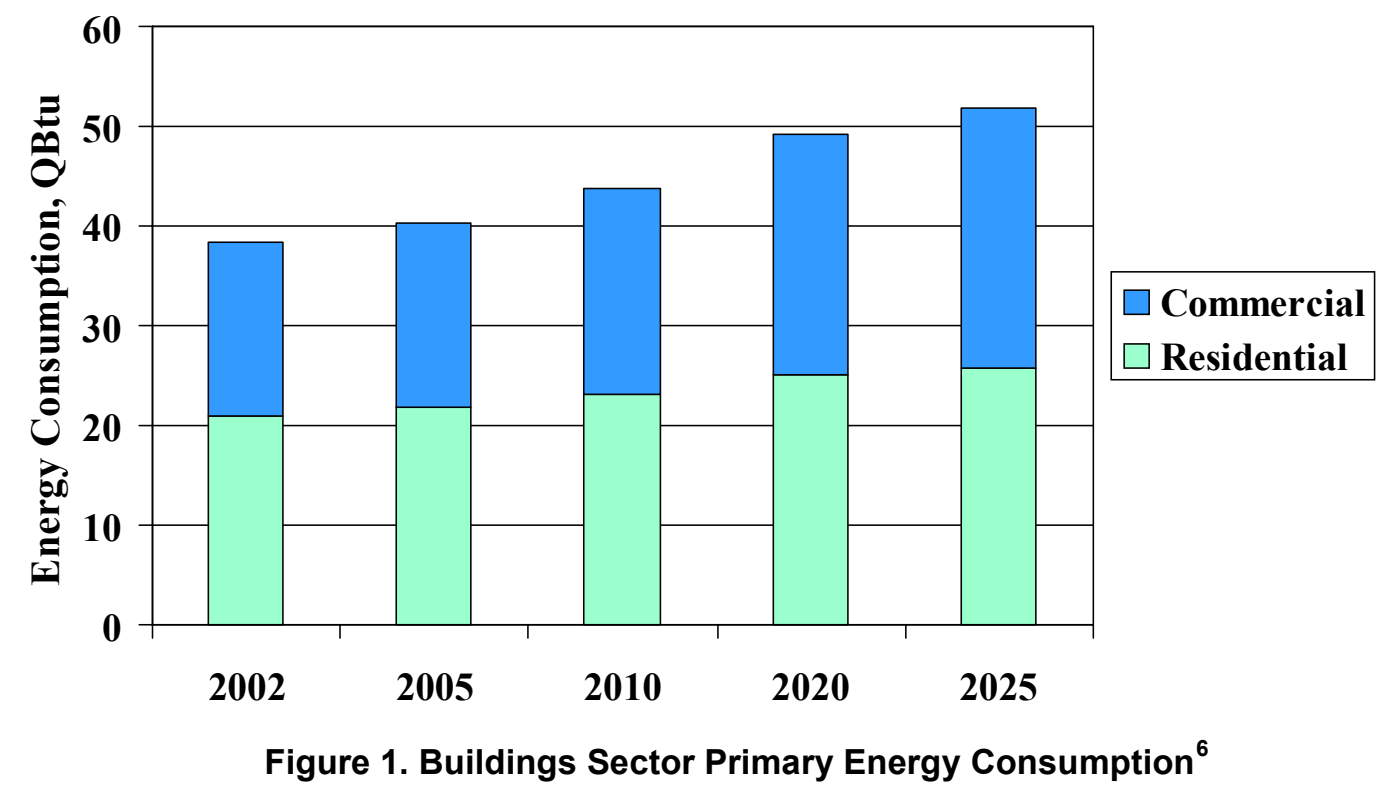

In 2003, there were more than 112 million households and 70 billion square feet of commercial floor space. Each year, more than 1 million new housing units and 2 billion

\footnotetext{
${ }^{1}$ Buildings Energy Data Book (BED), August 2004, Table 1.1.1, Table 1.3.11

${ }^{2}$ BED, Table 1.2.1

${ }^{3}$ BED, Table 1.3.4

${ }^{4}$ BED, Table 1.3.11

${ }^{5}$ BED, Table 1.1.1

${ }^{6} \mathrm{BED}$, Tables 1.2.1 and 1.3.1
} 
square feet of commercial floor space are built. ${ }^{7}$ Of the new housing units built, approximately 10\% built in 2004 qualified for Energy Star, ${ }^{8}$ and approximately 26,700 homes have been built to date by participating Building America research partners. ${ }^{9}$ Additionally, almost 2,000 commercial and institutional buildings (representing about 400 million square feet) have qualified for the Energy Star label. This is equivalent to about $0.04 \%$ of all commercial buildings and $0.56 \%$ of commercial square footage. ${ }^{10}$

Within the residential sector, the greatest energy uses among equipment are gas furnaces, incandescent lights, central air conditioning, refrigeration, and electric and gas water heating. ${ }^{11}$ Refrigerator energy efficiency, measured in $\mathrm{kWh} / \mathrm{unit} / \mathrm{year}$, has greatly improved during the past 15 years. ${ }^{12}$ Gas furnace sales are now $30 \%$-plus in the $90 \%$ Annual Fuel Utilization Efficiency (AFUE)-and-over condensing range, with DOE/EPA Energy Star actively labeling these condensing units as Energy Star. Absent heat-pump breakthroughs, gas heating technology is at its physical-efficiency limit, as units nearing $100 \%$ efficiency are commercially available. ${ }^{13}$

By contrast, the efficiency picture for incandescent lights, and electric and gas water heating use, offers less evidence of success to date. Incandescent lights use more than 2 QBtu and have a low luminous efficacy - about 75\% lower than fluorescent lighting, for example. Lighting offers large opportunities for efficiency gains, both because replacing incandescents with fluorescents saves a lot of energy, and also because the first cost differential continues to fall. Water heaters, which use roughly the same amount of energy, by contrast, do not offer consumers much in the way of efficiency/technology choice, and consequently there are no current Energy Star labels for water heating.

Within the commercial sector, the largest equipment energy users are fluorescent and incandescent lighting, rooftop and unitary air-conditioning, nonpersonal computer (PC) office equipment, supply/return fans, and packaged heating. ${ }^{14}$ EIA anticipates only moderate growth in energy consumption for space heating, space cooling, and lighting due to current and proposed appliance standards. ${ }^{15}$ However, as lighting consumes more than 3.8 QBtu of energy, it represents a great area of opportunity with the introduction of "Super T-8s"; lighting controls; compact fluorescents (CFLs); and, in the future, lightemitting diodes (LEDs).

\footnotetext{
${ }^{7}$ Annual Energy Outlook 2005, Tables A.4 and A.5

${ }^{8}$ EPA Press Release, "Nearly One in 102004 Homes Qualified for Energy Star." EPA Press Release \#R037, March 3, 2005.

${ }^{9} \mathrm{http} / / /$ www.eere.energy.gov/buildings/building_america/cfm/project_locations.cfm

${ }^{10}$ EPA Press Release, "EPA's List of Most Energy Efficient Buildings Nears 2000.” EPA Press Release \#R012, January 25, 2005.

${ }^{11}$ DOE/BT, "The Revised FY 2006 AOP Process," Guide for Evaluation of Energy Savings Potential, January 19, 2005. Table B.

${ }^{12}$ McMahon, et al. Impacts of U.S. Appliance Standards to Date. LBNL-45825.

${ }^{13}$ ACEEE Consumer Guide: Top-Rated Energy Efficient Appliances: Gas and Oil Furnaces, accessed at http://www.aceee.org/consumerguide/topfurn.htm

${ }^{14}$ DOE/BT, “The Revised FY 2006 AOP Process," Guide for Evaluation of Energy Savings Potential, January 19, 2005. Table D.

${ }^{15}$ Annual Energy Outlook 2005
} 


\section{Market Drivers}

At the most aggregate level of resolution, there are five primary markets within the buildings sector: new and retrofit homes, new and retrofit commercial buildings, and equipment/appliance sales (see Figure 2). The primary factors that influence (or drive) decision-making within the building market as a whole include interest rates, financing institutions, demographic factors, architects/engineers, general contractors, the demand for amenities, advertisers, and codes and standards. Additional drivers of decisionmaking in the equipment and appliance market include retailers, manufacturers, and Energy Star.

\begin{tabular}{|c|c|c|c|}
\hline \multirow{2}{*}{$\begin{array}{l}\text { New Homes } \\
\text { - Interest rates } \\
\text { - Tax treatment } \\
\text { - Demographic factors } \\
\text { - Teleworking } \\
\text { - Demand for amenities } \\
\text { - Advertising }\end{array}$} & & \multicolumn{2}{|c|}{$\begin{array}{l}\text { New Buildings } \\
\text { - Architects } \\
\text { - Contractors } \\
\text { - ASHRAE/local codes } \\
\text { - HVAC engineers }\end{array}$} \\
\hline & \multicolumn{2}{|c|}{$\begin{array}{l}\text { Equipment/Appliance Sales } \\
\text { - Buyers } \\
\text { - Builders/designers/developers } \\
\text { - Retailers } \\
\text { - HVAC installers } \\
\text { - Fed Standards/Energy Star } \\
\text { - Manufacturers } \\
\text { - Energy Service Providers }\end{array}$} & \\
\hline $\begin{array}{l}\text { Homes - Retrofit } \\
\text { - Owners } \\
\text { - Assessors/Appraisers } \\
\text { - Advertisers/retailers } \\
\text { - General contractors } \\
\text { - Fed Govt - standards/I } \\
\text { - HVAC installers } \\
\text { - Energy Service Provid }\end{array}$ & $\begin{array}{l}\text { - HVA } \\
\text { - Fed S } \\
\text { - Manı } \\
\text { - Ener }\end{array}$ & $\begin{array}{l}\text { s } \\
\text { Energy Star } \\
\text { Providers }\end{array}$ & $\begin{array}{l}\text { Buildings - Retrofit } \\
\text { - Capital providers } \\
\text { - Owners } \\
\text { - Real Estate Investment } \\
\text { Trust } \\
\text { - Local codes } \\
\text { - Tenants } \\
\text { - Energy service providers }\end{array}$ \\
\hline
\end{tabular}

Figure 2. Key Market Drivers

\section{Market Barriers ${ }^{16,17,18,19}$}

Market barriers in the buildings industry include a lack of information between the use of energy for a specific technology and its associated cost; the tradeoff between a lower lifecycle cost versus a lower first cost; principal-agent problems where the purchasing party

\footnotetext{
${ }^{16}$ Office of Policy and International Affairs, July 1996. Policies and Measures for Reducing Energy Related Greenhouse Gas Emissions: Lessons from Recent Literature. Office of Policy and International Affairs, U.S. Department of Energy.

${ }^{17}$ U.S. Congress, Office of Technology Assessment. May 1992. Building Energy Efficiency, OTA-E-518 (Washington, D.C.: U.S. Government Printing Office).

${ }^{18}$ Hassell, S., A. Wong, A. Houser, D. Knopman, M. Bernstein. 2003. "Building Better Homes: Government Strategies for Promoting Innovation in Housing." Science and Technology Policy Institute, RAND, for U.S. Department of Housing and Urban Development.

${ }^{19}$ National Energy Policy Development Group. May 2001. National Energy Policy, Chapter 4: Using Energy Wisely. Office of the President of the United States.
} 
is not responsible for paying the energy bills; time/availability barriers where users make emergency purchases due to equipment failure and are then limited to stock on hand; risk barriers where users tend to purchase familiar products; and the belief held by builders that consumers are relatively unwilling to invest in energy efficiency (e.g., luxury items such as marble countertops are more attractive than increased air-conditioner efficiency) (see Figure 3).

Additionally, the way in which the buildings industry is set up creates inherent barriers to the diffusion of energy efficiency. Because the industry is highly competitive, innovative measures are seen as more risky. Boom-bust cycles and small- to medium-size home builders equate too few resources for training and innovation; and multiple independent parties (e.g., architects/designers, contractors, developers) make it difficult to coordinate innovation and share information.

\begin{tabular}{|c|c|c|c|}
\hline \multicolumn{2}{|c|}{$\begin{array}{l}\text { New Homes } \\
\text { - Decisions made by builders, not owners } \\
\text { who pay bills } \\
\text { - Fragmented \& risk-averse industry } \\
\text { - Stick built with untrained labor force } \\
\text { - Lack of energy consciousness } \\
\text { - Financing mechanisms for efficiency } \\
\text { - Renters/Owners }\end{array}$} & \multicolumn{2}{|c|}{$\begin{array}{l}\text { New Buildings } \\
\text { - Energy not significant portion of most building } \\
\text { expenditures } \\
\text { - } 1 \text {-2 year payback vs. LCC focus } \\
\text { - If energy not "in" at financing stage, it's "out" } \\
\text { - Granite entryway vs. AC } \\
\text { - Lack of credible info re best ROI for efficiency } \\
\text { - Speculative building }\end{array}$} \\
\hline & \multirow{2}{*}{\multicolumn{2}{|c|}{$\begin{array}{l}\text { Equipment/Appliance Sales } \\
\text { - Purchase in emergency when unit } \\
\text { fails } \\
\text { - Household income } \\
\text { - First cost focus } \\
\text { - Despite Energy Star, lack of } \\
\text { information about cost/performance } \\
\text { - Commodity not attribute } \\
\text { - Efficiency generally not tax } \\
\text { advantaged }\end{array}$}} & $\begin{array}{l}\text { part about this sector } \\
\text { - As built vs intended design }\end{array}$ \\
\hline \multirow{2}{*}{$\begin{array}{l}\text { Homes - Retrofit } \\
\text { - Lack of energy awareness } \\
\text { - Lack of objective energy ROI } \\
\text { info } \\
\text { - Household income } \\
\text { - Granite countertop vs.AC } \\
\text { - Perceptions about resale ROI } \\
\text { - No nationally known MPG } \\
\text { analog }\end{array}$} & & & $\begin{array}{l}\text { Buildings - Retrofit } \\
\text { - See above } \\
\text { - Renovations rarely energy } \\
\text { driven } \\
\text { - Competition with other } \\
\text { uses of scarce capital }\end{array}$ \\
\hline & & & $\begin{array}{l}\text { - Cost/difficulty - window } \\
\text { change out in } 30 \text { story } \\
\text { building, e.g. }\end{array}$ \\
\hline
\end{tabular}

Figure 3. Key Market Barriers

\section{Key market actors and stakeholders}

Key market actors and stakeholders in the buildings industry include buyers/owners, Realtors, general contractors, developers, code officials, banks/lenders, energy service providers, property management firms, retailers, manufacturers, and advertisers (see Figure 4). 


\begin{tabular}{|c|c|c|c|}
\hline \multirow[t]{2}{*}{$\begin{array}{l}\text { New Homes } \\
\text { - Buyers } \\
\text { - Advertisers } \\
\text { - Realtors } \\
\text { - Homebuilders } \\
\text { - Code officials } \\
\text { - Banks/lenders }\end{array}$} & & \multicolumn{2}{|c|}{$\begin{array}{l}\text { New Buildings } \\
\text { - Capital providers, investors } \\
\text { - Users } \\
\text { - Developers, contractors } \\
\text { - Property management firms } \\
\text { - Architects } \\
\text { - Codes officials/ASHRAE }\end{array}$} \\
\hline & \multirow{2}{*}{\multicolumn{2}{|c|}{$\begin{array}{l}\text { Equipment/Appliance Sales } \\
\text { - Buyers } \\
\text { - Builders/designers/developers } \\
\text { - Retailers } \\
\text { - HVAC installers } \\
\text { - Fed Standards/Energy Star } \\
\text { - Manufacturers } \\
\text { - Energy Service Providers }\end{array}$}} & \\
\hline \multirow{2}{*}{\multicolumn{2}{|c|}{$\begin{array}{ll}\text { Homes - Retrofit } & \bullet \mathrm{B} \\
\cdot \text { - Owners } & \bullet \mathrm{R} \\
\text { - Assessors/Appraisers } & \bullet \mathrm{F} \\
\text { - Advertisers/retailers } & \bullet \mathrm{E} \\
\text { - General contractors } & \\
\text { - Fed Govt - standards/Energy Star } \\
\text { - HVAC installers } \\
\text { - Energy Service Providers }\end{array}$}} & & $\begin{array}{l}\text { Buildings - Retrofit } \\
\text { - Capital providers } \\
\text { - Owners } \\
\text { - Real Estate Investment Trust } \\
\text { - Local codes }\end{array}$ \\
\hline & & & $\begin{array}{l}\text { - Tenants } \\
\text { • Energy service providers }\end{array}$ \\
\hline
\end{tabular}

Figure 4. Key Market Actors

Current activities and impacts in the sector ${ }^{20}$

WIP funds a number of activities in the buildings sector, spending more than $\$ 260$ million annually in FY03-FY05. These activities include low-income weatherization, which has provided weatherization services to more than 5.3 million low-income families, ${ }^{21}$ with an average savings of $15 \%$ of household energy bills amounting to approximately $\$ 274$ per year, ${ }^{22}$ State Energy Grants, with an annual energy savings of 42.3 million Btu and annual cost savings of $\$ 256$ million; ${ }^{23}$ Rebuild America, with annual savings of nearly 9 trillion Btu and $\$ 131$ million in energy cost savings; ${ }^{24}$ and Building Codes Training and Assistance, with energy savings of nearly $\$ 1$ billion per year and improvements to the energy efficiency of nearly 3 billion square feet of new commercial floor space and nearly 4 million new households. ${ }^{25}$

Other federal, state and local, and industry programs that are influencing this market include Energy Star; building codes - e.g., American Society of Heating, Refrigerating and Air-Conditioning Engineers (ASHRAE) standards, and the International Energy Conservation Code (IECC); appliance and equipment standards; state energy programs,

\footnotetext{
${ }^{20}$ Following the completion of this analysis in FY05, responsibility for Rebuild America and Building Codes Training and Assistance was transferred to EERE's Building Technologies Program in FY06.

${ }^{21} \mathrm{http}: / / \mathrm{www}$.eere.energy.gov/weatherization/about.html

${ }^{22} \mathrm{http}: / / \mathrm{www}$.eere.energy.gov/weatherization/improving.html

${ }^{23} \mathrm{http} / / / \mathrm{www}$.eere.energy.gov/state_energy_program/goals_metrics.cfm\#metrics

${ }^{24} \mathrm{http}: / / \mathrm{www} \cdot$ rebuild.gov/aboutus/overview.asp

${ }^{25} \mathrm{http}: / / \mathrm{www} . e n e r g y c o d e s . g o v /$ whatwedo/
} 
including California Energy Commission (CEC) and New York State Energy Research and Development Authority (NYSERDA); and utility rebate or Demand-Side Management (DSM) programs. These programs invest close to \$2 billion, including \$201 million from the Low-Income Home Energy Assistance Program (LIHEAP), ${ }^{26}$ almost $\$ 1.6$ billion from State Energy Efficiency Programs, ${ }^{27}$ and more than $\$ 100$ million from other EERE offices (within Building Technologies, Solar, and Distributed Energy programs). ${ }^{28}$

\section{Market Impact Assessments}

\section{Energy-Savings Technical Potential}

Some of the most promising technologies and practices for the buildings sector are shown in Table 1. These technologies and practices were identified by the American Council for an Energy-Efficient Economy (ACEEE) ${ }^{29}$ as new technologies and practices that would be well-suited for market transformation activities, given their current low penetration rates $(<2 \%)$ in the market. Note that some activities, such as the High Performance Building Deployment and 30\% Above Code efforts, are not mutually exclusive because they target many of the same buildings. Therefore, the potential savings cannot be added.

Table 1. Potential Buildings Energy-Savings Potential

\begin{tabular}{|c|c|c|}
\hline Action Type & Clients & $\begin{array}{l}\text { Savings Potential } 2020 \\
\text { (Source TBtu) }^{30}\end{array}$ \\
\hline Whole Building Retrofit & $\begin{array}{l}\text { Consumers (Single Family), } \\
\text { Corporations (Mercantile/ } \\
\text { Service, Office), Institutions } \\
\text { (Education, Health Care) }\end{array}$ & Technical potential $\sim 3,500 \mathrm{TBtu}^{31}$ \\
\hline $\begin{array}{l}\text { Building America } \\
\text { Deployment (Zero net } \\
\text { energy homes) }\end{array}$ & Consumers (Single Family) & $\begin{array}{l}\sim 200 \text { (technical potential } \sim 2,500 \text { TBtu } \\
\text { at } 100 \% \text { market penetration) }\end{array}$ \\
\hline $\begin{array}{l}30 \% \text { Above Code in New } \\
\text { Commercial Construction }\end{array}$ & $\begin{array}{l}\text { Corporations, Institutions (New } \\
\text { Construction only) }\end{array}$ & $\begin{array}{l}\sim 600 \text { (technical potential } \sim 900 \text { TBtu at } \\
100 \% \text { market penetration) }\end{array}$ \\
\hline $\begin{array}{l}\text { High Performance } \\
\text { Building Deployment } \\
\text { (Ultra Low Energy } \\
\text { Commercial Building } \\
\text { Designs) }\end{array}$ & $\begin{array}{l}\text { Corporations } \\
\text { (Mercantile/Service, Office), } \\
\text { Institutions (Education, Health } \\
\text { Care) }\end{array}$ & $\begin{array}{l}\sim 200 \text { (technical potential } \sim 2,000 \text { TBtu } \\
\text { at } 100 \% \text { market penetration) }\end{array}$ \\
\hline
\end{tabular}

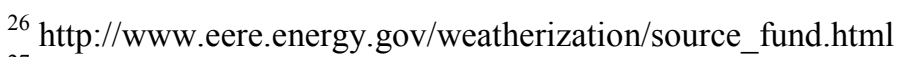

${ }^{27}$ Telephone interviews conducted by CEE, Northeast Energy Efficiency Partnerships and Kushler, York, \& Witte 2004

${ }^{28}$ Based on the DOE/EERE FY 2005 Budget Request.

${ }^{29}$ Sachs, H., S. Nadel, J. Thorne Amann, M. Tuazon, E. Mendelsohn, L. Rainer, G. Todesco, D. Shipley, and M. Adelaar. Emerging Energy-Saving Technologies and Practices for the Buildings Sector as of 2004. October 2004. ACEEE, Report Number A042.

${ }^{30}$ Ibid.

${ }^{31}$ PNNL calculations based on residential and commercial energy consumption, documented in the Appendix to this section.
} 


\begin{tabular}{|c|c|c|}
\hline $\begin{array}{l}\text { Increase CFL } \\
\text { penetration in homes }\end{array}$ & Consumers & $\begin{array}{l}\sim 600 \text { (technical potential } \sim 1,200 \text { TBtu } \\
\text { at } 100 \% \text { market penetration) }\end{array}$ \\
\hline $\begin{array}{l}\text { Advanced Residential } \\
\text { Water Heating }\end{array}$ & Consumers & $\begin{array}{l}\sim 400 \text { (technical potential } \sim 800 \text { TBtu at } \\
100 \% \text { market penetration) }\end{array}$ \\
\hline $\begin{array}{l}\text { Commercial Lighting } \\
\text { High-Efficacy Options }\end{array}$ & Commercial, Institutional & $\begin{array}{l}\sim 500 \text { (technical potential } \sim 500-750 \\
\text { TBtu at } 100 \% \text { market penetration) }\end{array}$ \\
\hline
\end{tabular}

\section{Potential for Regional Activities}

In 2003, almost half (46\%) of new single-family homes were built in the south census region, ${ }^{32}$ where more than $36 \%$ of the existing residential stock is located. ${ }^{33}$ The south census region also presents opportunities in the commercial sector, with approximately $35 \%$ of the commercial square footage located in that region. ${ }^{34}$ This region accounted for $39 \%$ of residential energy use and $37 \%$ of commercial energy use in $2001 .{ }^{35}$ Targeted efforts in these states ${ }^{36}$ would represent an efficient use of scarce resources.

\footnotetext{
${ }^{32}$ BED, Table 2.1.8

${ }^{33}$ BED, Table 2.1.3

${ }^{34}$ BED, Table 2.2.4

${ }^{35}$ Energy Information Administration. State Energy Data 2001: Consumption. Table R.1.

${ }^{36}$ The south census region is comprised of Delaware, Maryland, District of Columbia, Virginia, West Virginia, North Carolina, South Carolina, Georgia, Florida, Kentucky, Tennessee, Mississippi, Alabama, Arkansas, Louisiana, Oklahoma, and Texas.
} 


\section{Buildings Sector Appendix}

Table A-1. Energy Use by Energy-User Group

\begin{tabular}{|c|c|}
\hline $\begin{array}{l}\text { Sector - Major Groups of } \\
\text { Energy Users }\end{array}$ & $\begin{array}{r}\text { Current Energy Use - } \\
\text { Primary QBtu }\end{array}$ \\
\hline Residential $^{37}$ & 20.91 \\
\hline Single Family & 16.57 \\
\hline Multifamily & 3.05 \\
\hline Mobile Home & 1.29 \\
\hline Commercial $^{38}$ & 17.40 \\
\hline Office & 3.86 \\
\hline Mercantile & 2.61 \\
\hline Education & 1.72 \\
\hline Health Care & 1.44 \\
\hline Warehouse/Storage & 1.32 \\
\hline Food Service & 1.27 \\
\hline Lodging & 1.24 \\
\hline Public Assembly & 1.08 \\
\hline Service & 0.99 \\
\hline Food Sales & 0.78 \\
\hline Other & 0.52 \\
\hline Vacant & 0.35 \\
\hline Public Order/Safety & 0.24 \\
\hline Industrial $^{39}$ & 1.96 \\
\hline
\end{tabular}

Table A-2. Residential and Commercial Sector Energy Consumption by State ${ }^{40}$

\begin{tabular}{|l|r|r|}
\hline State & $\begin{array}{l}\text { Residential Sector } \\
\text { Consumption (TBtu) }\end{array}$ & $\begin{array}{l}\text { Commercial Sector } \\
\text { Consumption (TBtu) }\end{array}$ \\
\hline Alaska & 53.2 & 65.4 \\
\hline Alabama & 379.9 & 253.5 \\
\hline Arkansas & 218.5 & 148.1 \\
\hline Arizona & 344.0 & 311.9 \\
\hline California & $1,445.7$ & $1,508.8$ \\
\hline Colorado & 302.8 & 287.1 \\
\hline Connecticut & 266.5 & 215.0 \\
\hline District of Columbia & 34.2 & 104.0 \\
\hline Delaware & 62.1 & 51.6 \\
\hline Florida & $1,192.6$ & 958.4 \\
\hline Georgia & 642.0 & 502.9 \\
\hline Hawaii & 34.9 & 38.6 \\
\hline lowa & 229.3 & 179.0 \\
\hline Idaho & 104.8 & 94.5 \\
\hline
\end{tabular}

\footnotetext{
${ }^{37}$ Total energy use from Buildings Energy Data Book (BED), August 2004, Table 1.2.1; percentage primary consumption by building type from 2001 RECS, Table CE1-4c

${ }^{38}$ BED, August 2004, Tables 1.3.4 and 1.3.7

${ }^{39}$ BED, August 2004, Table 1.3.11

${ }^{40}$ Energy Information Administration. State Energy Data 2001: Consumption
} 


\begin{tabular}{|c|c|c|}
\hline Illinois & 928.2 & 829.1 \\
\hline Indiana & 504.0 & 397.4 \\
\hline Kansas & 215.4 & 192.0 \\
\hline Kentucky & 339.0 & 246.1 \\
\hline Louisiana & 347.8 & 263.5 \\
\hline Massachusetts & 460.7 & 379.4 \\
\hline Maryland & 391.0 & 372.3 \\
\hline Maine & 110.9 & 73.8 \\
\hline Michigan & 789.5 & 598.2 \\
\hline Minnesota & 380.7 & 335.6 \\
\hline Missouri & 495.9 & 389.1 \\
\hline Mississippi & 234.1 & 162.8 \\
\hline Montana & 69.8 & 59.8 \\
\hline North Carolina & 640.6 & 513.1 \\
\hline North Dakota & 61.0 & 55.5 \\
\hline Nebraska & 152.3 & 129.8 \\
\hline New Hampshire & 86.7 & 65.3 \\
\hline New Jersey & 572.8 & 554.3 \\
\hline New Mexico & 107.1 & 122.4 \\
\hline Nevada & 147.1 & 107.9 \\
\hline New York & $1,194.3$ & $1,303.2$ \\
\hline Ohio & 892.0 & 682.2 \\
\hline Oklahoma & 297.8 & 232.5 \\
\hline Oregon & 251.7 & 207.6 \\
\hline Pennsylvania & 930.9 & 709.0 \\
\hline Rhode Island & 72.6 & 63.2 \\
\hline South Carolina & 321.7 & 235.4 \\
\hline South Dakota & 60.3 & 50.3 \\
\hline Tennessee & 500.0 & 369.2 \\
\hline Texas & $1,569.9$ & $1,356.0$ \\
\hline Utah & 139.6 & 140.1 \\
\hline Virginia & 548.9 & 533.8 \\
\hline Vermont & 47.8 & 32.7 \\
\hline Washington & 471.2 & 376.8 \\
\hline Wisconsin & 400.8 & 312.6 \\
\hline West Virginia & 156.6 & 110.6 \\
\hline Wyoming & 39.3 & 50.8 \\
\hline United States & $20,240.5$ & $17,332.4$ \\
\hline
\end{tabular}


Table A-3. Technology Penetration by Energy-User Group, Existing Stock

\begin{tabular}{|c|c|c|c|}
\hline \multirow[t]{2}{*}{ Residential } & \multicolumn{3}{|c|}{$\%$ of Households } \\
\hline & $1990^{41}$ & $1997^{42}$ & $2001^{43}$ \\
\hline \multicolumn{4}{|l|}{ Heating } \\
\hline Heat Pump & $7.76 \%$ & $9.56 \%$ & $9.72 \%$ \\
\hline Furnace & $58.28 \%$ & $59.31 \%$ & $62.80 \%$ \\
\hline Ind. Space Heat & $11.28 \%$ & $12.02 \%$ & $9.35 \%$ \\
\hline Boiler & $14.49 \%$ & $12.32 \%$ & $11.50 \%$ \\
\hline \multicolumn{4}{|l|}{ Cooling } \\
\hline Res Central Air & $31.06 \%$ & $50.14 \%$ & $55.73 \%$ \\
\hline Indiv/Room AC & $26.60 \%$ & $34.24 \%$ & $28.11 \%$ \\
\hline Heat Pump & $12.22 \%$ & $14.40 \%$ & $13.63 \%$ \\
\hline \multicolumn{4}{|c|}{ Water Heating } \\
\hline Centralized & $100.00 \%$ & $99.61 \%$ & $100.00 \%$ \\
\hline
\end{tabular}

Note: Percentages represent equipment present in household.

Household may contain more than one type of equipment per category.

\begin{tabular}{|l|r|r|r|}
\hline \multicolumn{1}{|c|}{ Commercial } & \multicolumn{3}{|c|}{$\%$ of Commercial Floorspace } \\
\hline \multicolumn{1}{|c|}{ Heating } & $1992^{44}$ & 1995 & 1999 \\
\hline Heat Pump & & & \\
\hline Furnace & $13.1 \%$ & $10.2 \%$ & $13.6 \%$ \\
\hline Ind. Space Heat & $26.0 \%$ & $25.8 \%$ & $23.3 \%$ \\
\hline Boiler & $35.9 \%$ & $30.5 \%$ & $27.5 \%$ \\
\hline Pkg Heating & $33.4 \%$ & $30.8 \%$ & $30.8 \%$ \\
\hline Other & $26.8 \%$ & $31.4 \%$ & $41.6 \%$ \\
\hline \multicolumn{1}{|c|}{ Cooling } & $2.7 \%$ & $11.0 \%$ & $4.8 \%$ \\
\hline Res Central Air & $15.0 \%$ & $17.7 \%$ & $13.4 \%$ \\
\hline Indiv/Room AC & $28.3 \%$ & $24.4 \%$ & $23.5 \%$ \\
\hline Heat Pump & $14.3 \%$ & $13.9 \%$ & $14.6 \%$ \\
\hline Central Chillers & $19.6 \%$ & $23.5 \%$ & $20.7 \%$ \\
\hline Pkg AC & $49.1 \%$ & $52.7 \%$ & $62.0 \%$ \\
\hline Other & $0.0 \%$ & $0.7 \%$ & $1.0 \%$ \\
\hline \multicolumn{1}{|c|}{ Lighting } & & & \\
\hline Incandescent & $61.1 \%$ & $63.8 \%$ & $59.0 \%$ \\
\hline Std Fluorescent & $95.2 \%$ & $95.4 \%$ & $93.8 \%$ \\
\hline Compact Fluorescent & $11.7 \%$ & $25.1 \%$ & $31.8 \%$ \\
\hline High Intensity Discharge & $25.2 \%$ & $26.3 \%$ & $29.4 \%$ \\
\hline Halogen & & $16.4 \%$ & $26.7 \%$ \\
\hline \multicolumn{1}{|c|}{ Water Heating } & & & \\
\hline Centralized & $54.3 \%$ & $61.4 \%$ & $63.4 \%$ \\
\hline Distributed & $50.3 \%$ & $31.5 \%$ & $18.1 \%$ \\
\hline Combined & & $4.9 \%$ & $15.8 \%$ \\
\hline
\end{tabular}

Note: Percentages represent equipment present in building.

Building may contain more than one type of equipment per category.

\footnotetext{
${ }^{41} 1990$ Residential Energy Consumption Survey, EIA

421997 Residential Energy Consumption Survey, EIA

${ }^{43} 2001$ Residential Energy Consumption Survey, EIA

${ }^{44} 1992$ Commercial Buildings Energy Consumption Survey, EIA

${ }^{45} 1995$ Commercial Buildings Energy Consumption Survey, EIA

${ }^{46} 1999$ Commercial Buildings Energy Consumption Survey, EIA
} 


\section{WIP investments in the sector}

Table A-4. WIP Appropriations Summary for Buildings (\$ Million)

\begin{tabular}{|l|l|r|r|r|}
\hline Project & Activity & FY03 & FY04 & FY05 \\
\hline \multirow{2}{*}{ Weatherization } & Grants & 220.2 & 223.8 & 224.8 \\
\cline { 2 - 5 } & Training \& TA & 3.4 & 3.4 & 3.4 \\
\hline Rebuild America & & 11.0 & 10.0 & 8.7 \\
\hline Building Codes Training & & 4.6 & 4.4 & 5.6 \\
\hline Energy Star & & 4.2 & 3.7 & $0.0^{*}$ \\
\hline SEP Buildings Allocation & & 23.5 & 21.8 & 21.9 \\
\hline Buildings Total & & $\mathbf{2 6 6 . 9}$ & $\mathbf{2 6 7 . 1}$ & $\mathbf{2 6 4 . 4}$ \\
\hline
\end{tabular}

Note: Energy Star has been moved to the Building Technologies Program within EERE.

\section{Other Resource Investments in the Sector}

Table A-5. 2004 Energy Efficiency Budgets (1) ${ }^{47}$

\begin{tabular}{|c|c|c|c|}
\hline State & $\begin{array}{l}\text { Estimated Funding } \\
\text { (million \$) }\end{array}$ & State & $\begin{array}{l}\text { Estimated Funding } \\
\text { (million \$) }\end{array}$ \\
\hline Arizona & 2 & New Hampshire & 15 \\
\hline California & 540 & New Jersey & 108 \\
\hline Colorado & 25 & New York & 278 \\
\hline Connecticut & 49 & Ohio & 3 \\
\hline Illinois & 9 & Oregon & 40 \\
\hline lowa & 54 & Rhode Island & 15 \\
\hline Maine & 8 & Texas (2) & 68 \\
\hline Massachusetts & 132 & Vermont & 16 \\
\hline Michigan & 10 & Washington & 31 \\
\hline Minnesota (2) & 57 & Wisconsin & 39 \\
\hline Montana & 9 & BPA Programs & 35 \\
\hline Nevada & 11 & TOTAL & 1.584 Billion \\
\hline
\end{tabular}

Notes:

1. Budgets are for 2004 unless otherwise indicated. In all cases, budgets are moving targets. Budgets for some of the states are estimates based on the prior year.

2. 2003 estimated budget

3. Programs administered by Bonneville Power Administration in the Pacific Northwest. The BPA figure is understated.

\footnotetext{
${ }^{47}$ Telephone interviews conducted by Consortium for Energy Efficiency (CEE), Northeast Energy Efficiency Partnerships and Kushler, York, \& Witte 2004
} 


\section{Energy-Savings Potential}

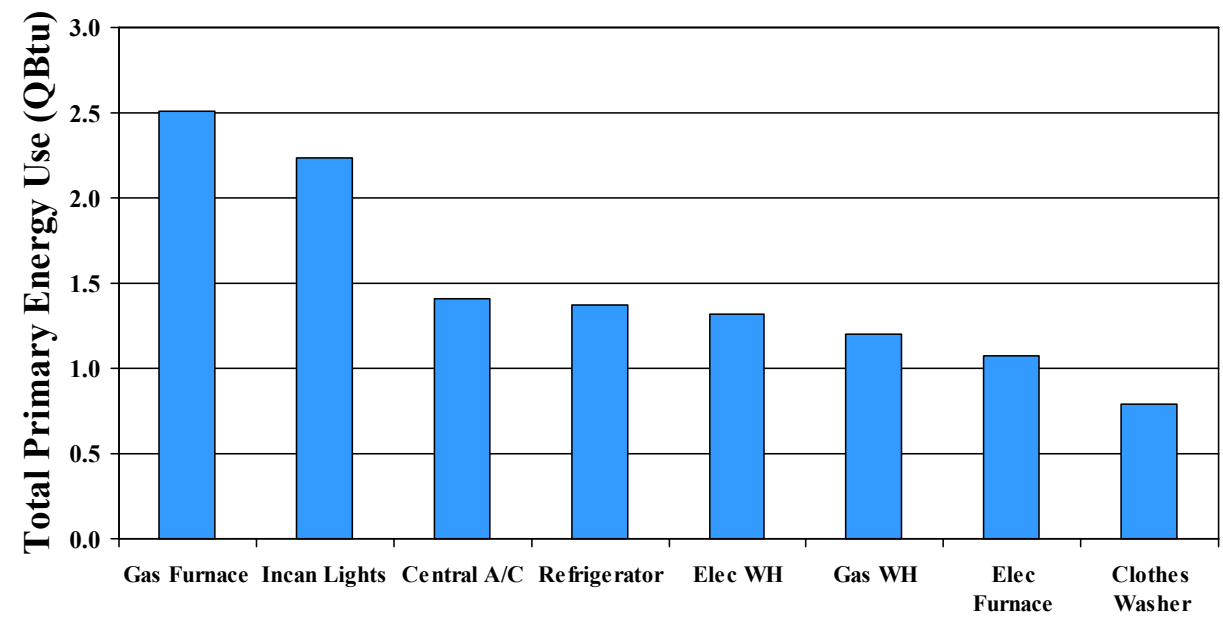

Figure A-1. Largest Equipment Uses - Residential ${ }^{48}$

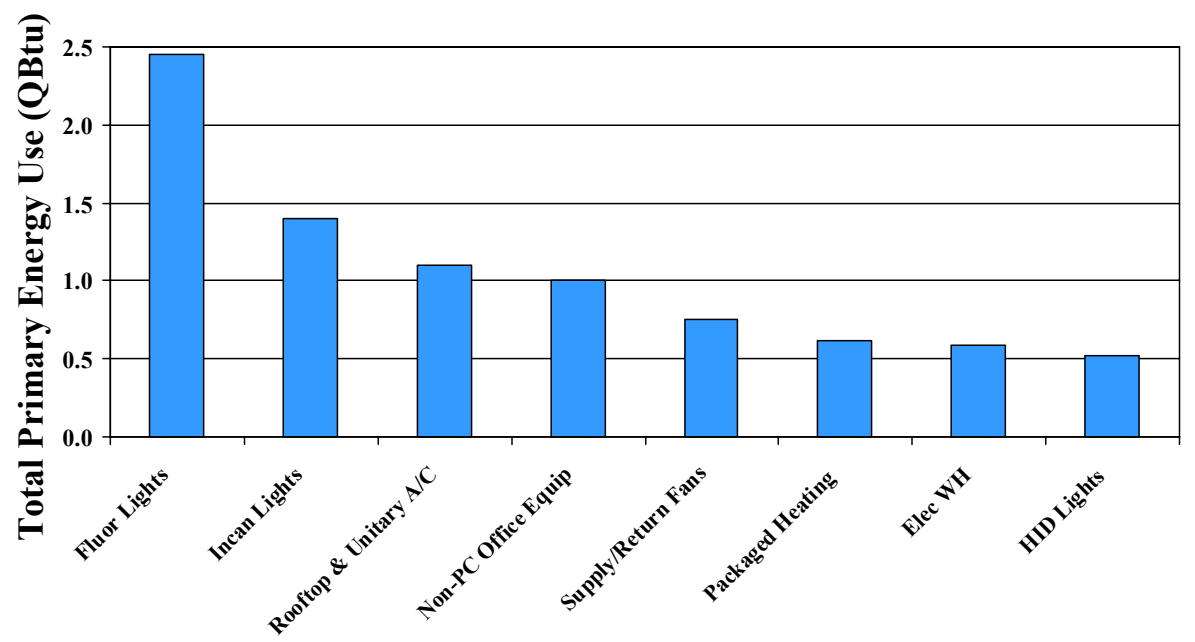

Figure A-2. Largest Equipment Uses - Commercial ${ }^{49}$

\section{Technical Potential Calculations}

Technical potential savings were calculated as follows:

Building America Deployment: The ACEEE report ${ }^{50}$ calculated savings information for "Zero (Net) Energy Houses, Including Houses with > 50\% Energy Savings" of 199 source TBtu in 2020, assuming a feasible penetration of $8 \%$. PNNL extrapolated this number to represent $100 \%$ penetration (199 TBtu / 8\% * 100\% $=2,487 \mathrm{TBtu})$.

\footnotetext{
${ }^{48}$ DOE/BT, “The Revised FY 2006 AOP Process," Guide for Evaluation of Energy Savings Potential, January 19, 2005. Table B.

${ }^{49}$ DOE/BT, "The Revised FY 2006 AOP Process," Guide for Evaluation of Energy Savings Potential, January 19, 2005. Table D.

${ }^{50}$ Sachs, H., S. Nadel, J. Thorne Amann, M. Tuazon, E. Mendelsohn, L. Rainer, G. Todesco, D. Shipley, and M. Adelaar. Emerging Energy-Saving Technologies and Practices for the Buildings Sector as of 2004. October 2004. ACEEE, Report Number A042. Pages 158-159.
} 
Whole-Building Retrofits: No similar activity was represented in the ACEEE report. PNNL, therefore, calculated technical potential using the Buildings Energy Data Book ${ }^{51}$ to develop rough estimates as follows:

- Residential: Approximately $80 \%$ of residential energy use occurs in single-family housing (BED Table 1.2.6); approximately 14.3 QBtu were used in the residential sector for space heating, space cooling, water heating, and lighting (BED Table 1.2.3); and the whole-building retrofit goal would be to reduce energy use in those end uses by $20 \%$, yielding approximately $2,300 \mathrm{TBtu}$.

- Commercial/Institutional: Approximately 10.0 QBtu were used in the commercial sector for space heating, space cooling, water heating, and lighting (BED Table 1.3.3); approximately $60 \%$ of commercial energy use occurs in mercantile/service, office, education, and health-care buildings (BED Table 1.3.7); and the whole building retrofit goal would be to reduce energy use in those end uses by $20 \%$, yielding approximately 1,200 TBtu.

High-Performance Building Deployment: The ACEEE report ${ }^{52}$ calculated savings information for "Ultra Low Energy Commercial Building Designs (50\% > Codes)" of 199 source TBtu in 2020, assuming a feasible penetration of 10\%. PNNL extrapolated this number to represent 100\% penetration (199 TBtu / 10\% *100\% $=1,990 \mathrm{TBtu})$.

30\% Above Code: The ACEEE report ${ }^{53}$ calculated savings information for "Integrated Commercial Building Design (30\% > Code)" of 620 source TBtu in 2020, assuming a feasible penetration of $68 \%$. PNNL extrapolated this number to represent $100 \%$ penetration $(620 \mathrm{TBtu} / 68 \% * 100 \%=912 \mathrm{TBtu})$.

Increase CFL Penetration in Homes: Currently, incandescent lighting uses more than 2.0 QBtu annually. Assuming that CFLs save about $60 \%$ over incandescent lighting, the technical potential is about $60 \%$ of the incandescent consumption.

Advanced Residential Water Heating: The ACEEE report ${ }^{54}$ calculated savings information for "Residential Condensing Water Heaters" of 217 source TBtu in 2020, assuming a feasible penetration of $70 \%$ and for "Residential Heat Pump Water Heaters" of 158 source TBtu in 2020, assuming a feasible penetration of 30\%. PNNL extrapolated these numbers to represent $100 \%$ penetration $((217 \mathrm{TBtu} / 70 \% * 100 \%)+(158 \mathrm{TBtu} /$ $30 \% * 100 \%)=837 \mathrm{TBtu})$.

\footnotetext{
${ }^{51}$ Buildings Energy Databook, August 2004

${ }^{52}$ Sachs, H., S. Nadel, J. Thorne Amann, M. Tuazon, E. Mendelsohn, L. Rainer, G. Todesco, D. Shipley, and M. Adelaar. Emerging Energy-Saving Technologies and Practices for the Buildings Sector as of 2004. October 2004. ACEEE, Report Number A042. Pages 152-153.

${ }^{53}$ Sachs, H., S. Nadel, J. Thorne Amann, M. Tuazon, E. Mendelsohn, L. Rainer, G. Todesco, D. Shipley, and M. Adelaar. Emerging Energy-Saving Technologies and Practices for the Buildings Sector as of 2004. October 2004. ACEEE, Report Number A042. Pages 154-155.

${ }^{54}$ Sachs, H., S. Nadel, J. Thorne Amann, M. Tuazon, E. Mendelsohn, L. Rainer, G. Todesco, D. Shipley, and M. Adelaar. Emerging Energy-Saving Technologies and Practices for the Buildings Sector as of 2004. October 2004. ACEEE, Report Number A042. Pages 46-50.
} 
Commercial Lighting High-Efficacy Options: Currently, commercial fluorescent lighting uses almost 2.5 QBtu annually. Assuming that higher-efficacy fluorescents (such as "super T-8s" and scotopic lighting) save 20\%-30\% over standard fluorescent lighting, the technical potential would range from $20 \%-30 \%$ of the standard fluorescent consumption. 


\section{Clean-Energy Sector Analysis}

\section{Approach and Methodology}

The following analysis examines the market for renewable energy and energy efficiency in the electric sector from 1990 through 2025 and assesses potential opportunities for future market expansion. The analysis traces the historical factors that have influenced the growth and adoption of renewable energy-generating sources and presents estimates of the potential future market size in light of key market drivers and barriers.

The analysis relies on readily available information, including data from EIA and other Department of Energy (DOE) sources, as well as other reports prepared on renewable energy and demand-side management.

\section{Sector Characteristics}

\section{Baseline Data and Recent Market Trends}

Trends in the Electric Sector

In 2002, the base year for this analysis, U.S. electric-generating capacity totaled 876,700 MW and total annual generation was 3,678 billion kWh. Primary energy consumption in the electric power sector was 38.19 quadrillion Btus (quads) annually. Delivered electricity, accounting for plant efficiencies and transmission and distribution losses, was equivalent to 13.11 quads. Of the delivered electricity, $50 \%$ was generated from coal, followed by nuclear $(20 \%)$, natural gas $(18 \%)$, renewables $(9 \%)$, and petroleum $(2 \%)$

(Figure 5). Electricity consumption by enduse sector was fairly evenly distributed among residential $(36 \%)$, commercial $(34 \%)$, and

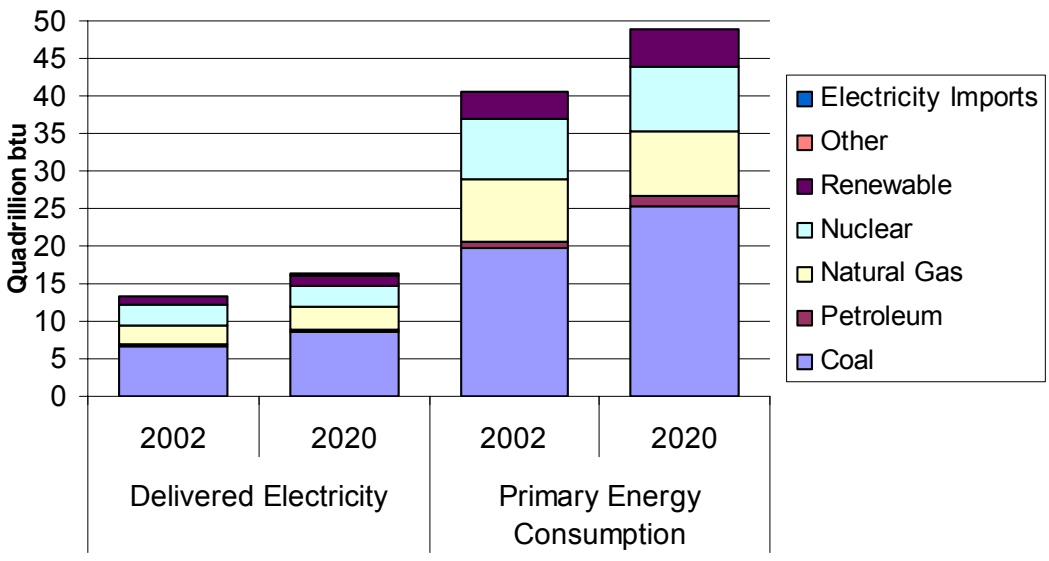

Figure 5. Primary and Delivered Energy Consumption in the Electric Sector industrial $(28 \%)$ users, with less than $1 \%$ used by the transportation sector. ${ }^{55}$

${ }^{55}$ EIA Annual Energy Outlook 2005, With Projections to 2025, DOE/EIA-0383(2005), preliminary release January 2005. http://www.eia.doe.gov/oiaf/aeo/index.html 
During the early to mid-1990s, energy consumption per capita increased with declining prices and strong economic growth. To meet growing demand, the vast majority of capacity additions were natural gas plants, because of their ability to meet air pollutant emissions standards and the relatively low cost of fuel. However, recent increases in the price of natural gas have led to a renewed interest in wind and coal-fired capacity.

Looking forward, the Energy Information Administration (EIA) projects that electricity sales will grow at an annual average rate of $1.9 \%$ through 2025 to

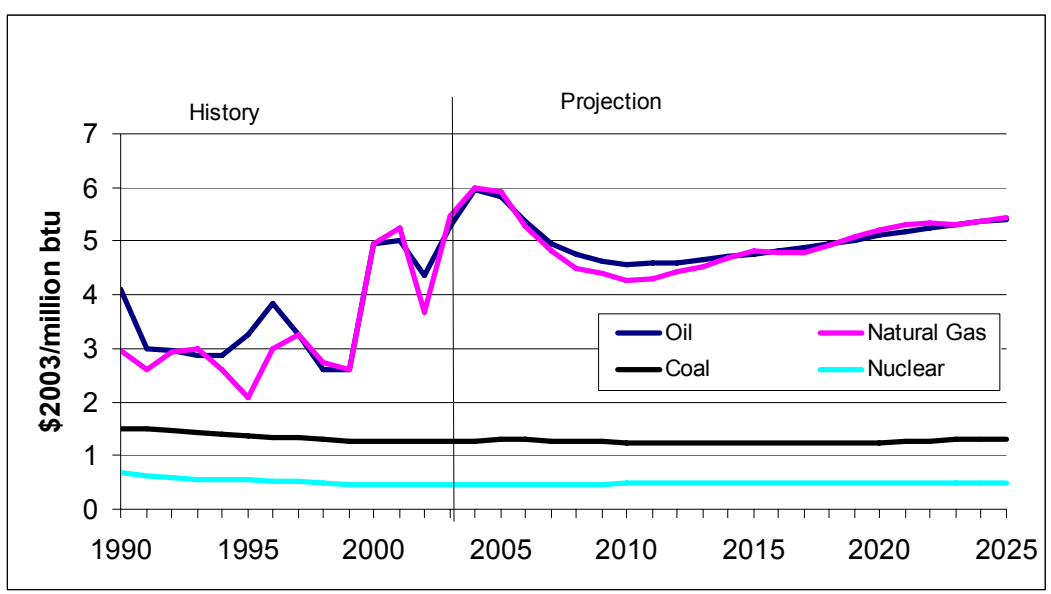

Figure 6. EIA Projections of Fuel Prices to Electric Generators (1990-2025) 5,220 billion $\mathrm{kWh}$ in 2025 , with sales to the commercial sector growing faster than in the residential and industrial sectors. With $43 \mathrm{GW}$ of inefficient, older generating capacity projected to be retired, EIA estimates that $281 \mathrm{GW}$ of new generation will be needed by 2025, bringing total installed capacity to $1,145 \mathrm{GW}$ by $2025 .^{56}$

Despite high fuel prices, more than $60 \%$ of the new capacity additions are projected to be natural gas-fired combined-cycle, combustion turbine, or distributed generation facilities. EIA projects that natural gas prices to drop to $\$ 4.3 / \mathrm{mmBtu}(\$ 2003)$ by 2010 and then rise again gradually through 2025 (Figure 6). ${ }^{57}$

Coal prices are expected to remain relatively flat over time in constant dollars. As natural gas prices rise later in the forecast, new coal-fired capacity becomes increasingly competitive, accounting for nearly one-third of the capacity expansion. EIA assumes that new nuclear facilities will not be economical. Of total generating capacity by 2025 , EIA projects that $34 \%$ will be coal, $46 \%$ natural gas and other fossil, $9 \%$ nuclear, and $9 \%$ renewable. Retail electricity prices are projected to increase slightly or stay at the current historic highs through 2025 (Figure 7).

\footnotetext{
${ }^{56}$ EIA (2005).

${ }^{57}$ EIA Renewable Energy Annuals, 1990-2003, http://www.eia.doe.gov/cneaf/solar.renewables/page/pubs.html.
} 
Renewable Energy

Historic Trends

In 2002, non-hydro

renewables accounted for

about $2 \%$ of total electric

generating capacity and

generation. Non-hydro

generation totaled 86

billion $\mathrm{kWh}$, of which

$17 \%$ was from

geothermal, followed by

$26 \%$ municipal solid

waste, $45 \%$ other

biomass, $1 \%$ solar, and

$12 \%$ wind.

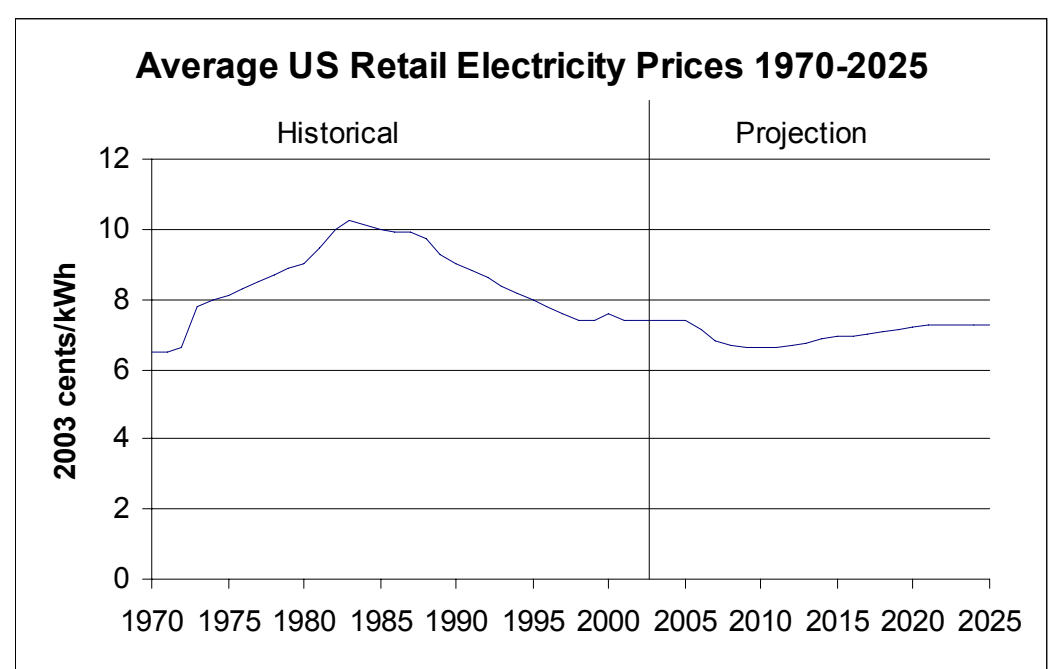

Figure 7. EIA Projection of Retail Electricity Prices

During the 1990s, renewables experienced both a period of growth and decline. For example, from 1990 through 2002, non-hydro renewable capacity grew from 13,700 MW to $16,800 \mathrm{MW}$, with $5,000 \mathrm{MW}$ of new capacity offset by losses of nearly 2,000 MW (Figure 8). ${ }^{58}$

During the early 1990s, most new capacity (primarily geothermal and biomass) was spurred by long-term contracts under Public Utilities Regulatory Policy Act (PURPA) and a federal production tax incentive for landfill gas facilities. In the mid- to late 1990s, this trend reversed to some degree and some biomass and geothermal facilities ceased operation when their PURPA

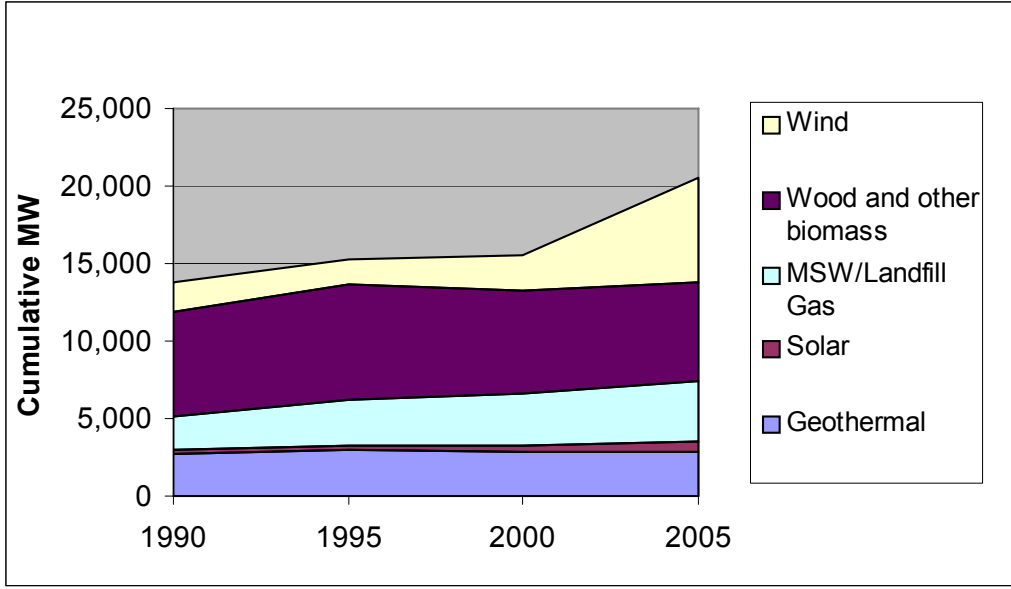

Figure 8. Cumulative Non-hydro Renewable Generating Capacity, 1990-2005

contracts expired. On the other hand, renewables also gained some ground during this period as a result of state policies and retail choice. In the late 1990s, a number of states adopted policies to encourage renewable energy development, typically to maintain public benefits during the movement toward retail competition.

\footnotetext{
${ }^{58}$ EIA Renewable Energy Annuals, 1990-2003, http://www.eia.doe.gov/cneaf/solar.renewables/page/pubs.html.
} 
Since then, most renewable capacity additions (primarily wind) have been driven by state renewable portfolio standards (RPS) or renewable energy mandates, voluntary purchases of renewable energy by consumers, integrated resource planning (particularly in western states with cost-effective wind resources), and system benefits funds. Figure 9 shows the fraction of renewable generating capacity attributed to each of the major policy or market drivers, based on a number of existing studies by NREL, Lawrence Berkeley National Laboratory (LBNL), and EIA. ${ }^{59} \mathrm{We}$ adjusted the estimates to account for doublecounting among the drivers. In addition, the

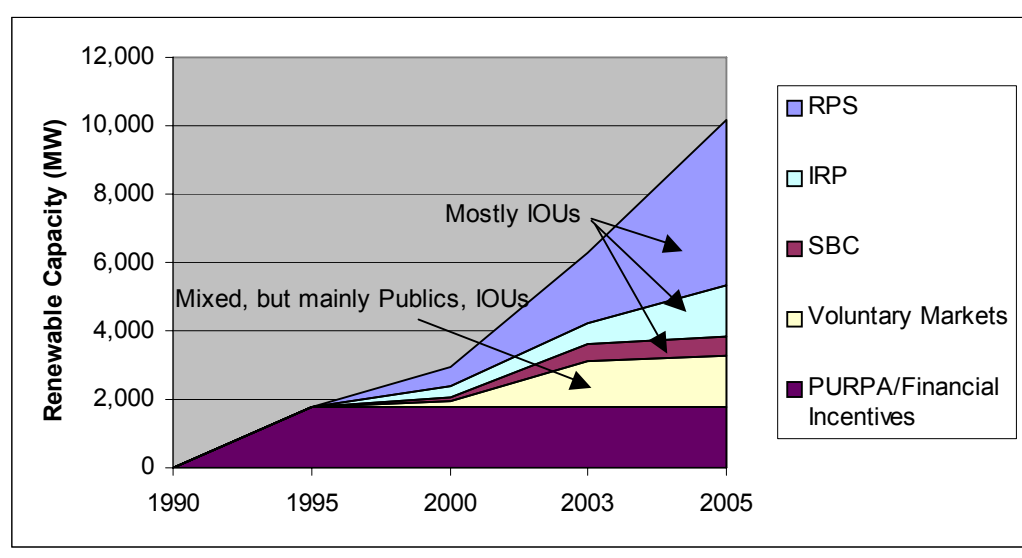

Figure 9. Recent Market Drivers for Renewables

federal PTC has been important for improving the economics of wind projects. While the extension of the PTC is uncertain, RPS, voluntary markets, and IRP are expected to be the most significant market drivers for renewables going forward.

By the end of 2005, EIA expects non-hydro renewable energy capacity to reach 21,080 MW and generate 115 billion kilowatt-hours $(\mathrm{kWh})$, or $3 \%$ of total generation. To date, 2005 is on track to be a record setting year for wind energy development, with the American Wind Energy Association expecting up to 2,500 MW of new wind energy capacity additions. If this occurs, the EIA projections will be exceeded.

\section{Market Segmentation: Renewables Penetration by Utility Type}

Most renewable energy facilities are owned by independent power producers. In 2003, $94 \%$ of U.S. renewable energy generating capacity was owned by nonutility generators, with $4 \%$ owned by public utilities, and $2 \%$ by IOUs.

\footnotetext{
${ }^{59}$ Bird, L. and B. Swezey, 2004. Estimates of New Renewable Capacity Serving Green Power Markets (2003), National Renewable Energy Laboratory, Golden, CO, March. http://www.eere.energy.gov/greenpower/resources/tables/new_gp_cap.shtml;

Bolinger, M., R. Wiser, L. Milford, M. Stoddard, and K. Porter, 2000. Clean Energy Funds: An Overview of State Support for Renewable Energy, Lawrence Berkeley National Laboratory, Berkeley, California, LBNL-47705, April.

Bird, L., B. Parsons, T. Gagliano, M. Brown, R. Wiser, and M. Bolinger, 2003. Policies and Market Factors Driving Wind Power Development in the United States, National Renewable Energy Laboratory, Golden, CO, NREL/TP-620-34599, July.

Petersick, T, 2004. State Renewable Energy Requirements and Goals: Status Through 2003, DOE/EIA http://www.eia.doe.gov/oiaf/analysispaper/rps/pdf/rps.pdf
} 
Figure 10 shows the fraction of renewables capacity of total generating capacity owned by utilities, according to utility type.$^{60}$ However, nonutility generators typically sell the output of renewable energy projects to local utilities through power purchase agreements. Data are not widely available on the entity purchasing the output, making it difficult to track purchases or investments in renewable energy generation among investorowned, municipal, and cooperative utilities.

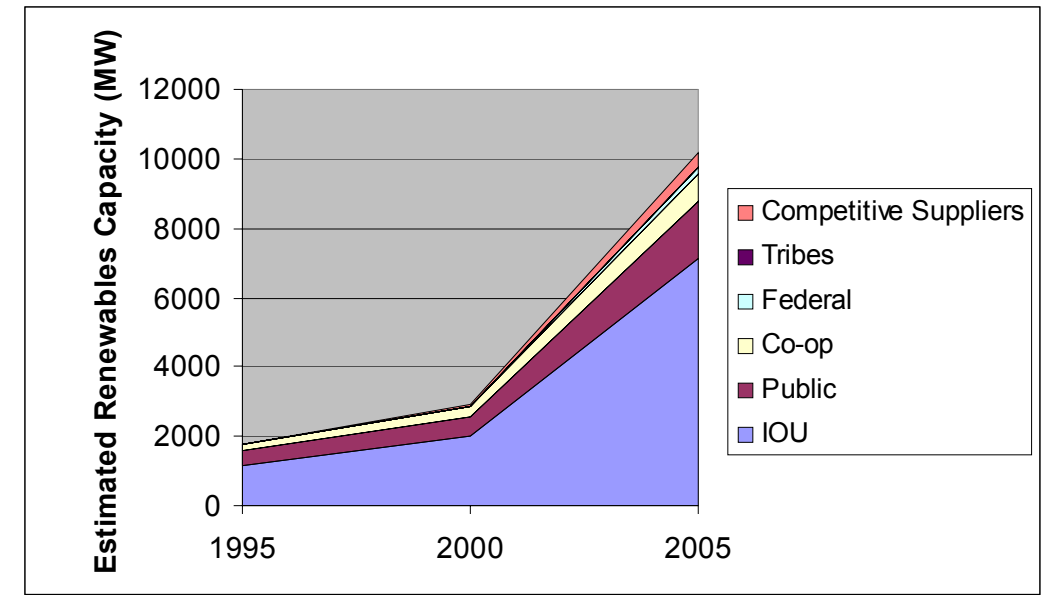

Figure 10. Renewables as Percent of Total Generating Capacity by Utility Ownership

An alternative approach to determining the magnitude of investment in renewables by utility type is to look at the primary drivers for renewable energy development, as some drivers apply only to particular utility types. For instance, RPS and system benefits charges typically pertain only to investorowned utilities (IOUs) and competitive electricity suppliers, with some exceptions (Figure 9). And while all types of utilities can use Integrated Resource Planning (IRP), IOUs are responsible for most of the largescale renewable capacity additions planned under recent IRPs. All types of utilities offer voluntary green power programs; although

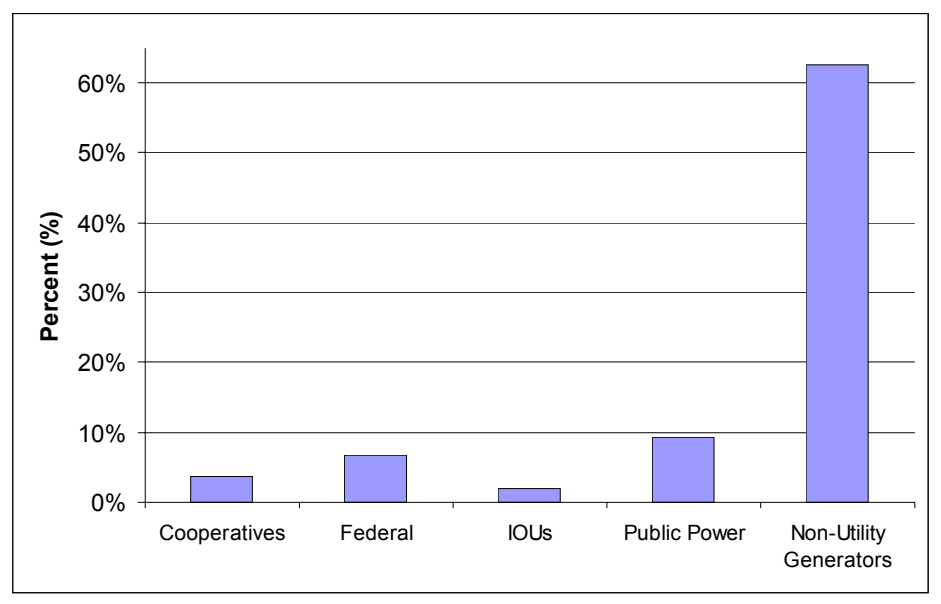

Figure 11. Estimated Capacity Additions by Type of Utility Purchaser

municipal utilities, in particular, have had significant success in implementing voluntary renewable energy programs. We present a rough estimate of the renewables capacity attributed to each of the major utility types, based on capacity additions resulting from key drivers and their applicability across utility types (Figure 11). Although this is a very rough estimate, it shows that IOUs, followed by public utilities, are responsible for most of the new capacity added from 1995 through 2005.

\footnotetext{
${ }^{60}$ Source: Energy Information Administration, Form EIA-860, as of December 31, 2003
} 
It is also important to note that IOUs represent only $7 \%$ of utilities in the United States, but represent $66 \%$ of electricity sales (Table 2). ${ }^{61}$ Thus, the largest opportunities for renewables may be with IOUs. However, there may be opportunities to work with publics and co-ops, because they are not the target of most existing policy drivers and may have greater interest in the public benefits that renewables provide.

Table 2. Number of Utilities and Annual Electric Sales by Utility Type, 2002

\begin{tabular}{|l|r|r|r|r|}
\hline & $\begin{array}{r}\text { Number of } \\
\text { Utilities }\end{array}$ & $\%$ & $\begin{array}{r}\text { Electric Sales } \\
\text { (million kWh) }\end{array}$ & $\%$ \\
\hline IOU & 217 & $7 \%$ & $2,151,889$ & $66 \%$ \\
\hline Publics & 1870 & $59 \%$ & 516,475 & $16 \%$ \\
\hline Co-ops & 889 & $28 \%$ & 333,745 & $10 \%$ \\
\hline Federal & 12 & $0 \%$ & 35,787 & $1 \%$ \\
\hline Power Marketers & 47 & $1 \%$ & 201,640 & $6 \%$ \\
\hline Total & 3035 & $100 \%$ & $3,239,536$ & $100 \%$ \\
\hline
\end{tabular}

Forecasts of Renewable Energy Market Penetration

Looking ahead, EIA projects slow growth for renewable energy technologies "both because of the relatively low costs of fossil-fired generation and because competitive electricity markets favor less capital-intensive technologies." 62 EIA estimates that nonhydro renewable energy capacity will grow to $28,350 \mathrm{MW}$ by 2020 and 33,780 MW by 2025 (Figure 12). ${ }^{63}$ This represents 7,280 MW of new capacity from 2005 to 2020 and 12,700 new MW by 2025. Non-hydro renewable generation is projected to grow from 115 billion $\mathrm{kWh}$ in 2005 to 182 billion $\mathrm{kWh}$ in 2025 , or $2.3 \%$ annually.

In its forecast, EIA assumes that the federal Production Tax Credit (PTC) will expire at the end of 2005. EIA also takes into account state mandates and renewable energy policies. EIA projects that state policies will lead to $1,600 \mathrm{MW}$ of new non-hydro renewable capacity through 2025. This

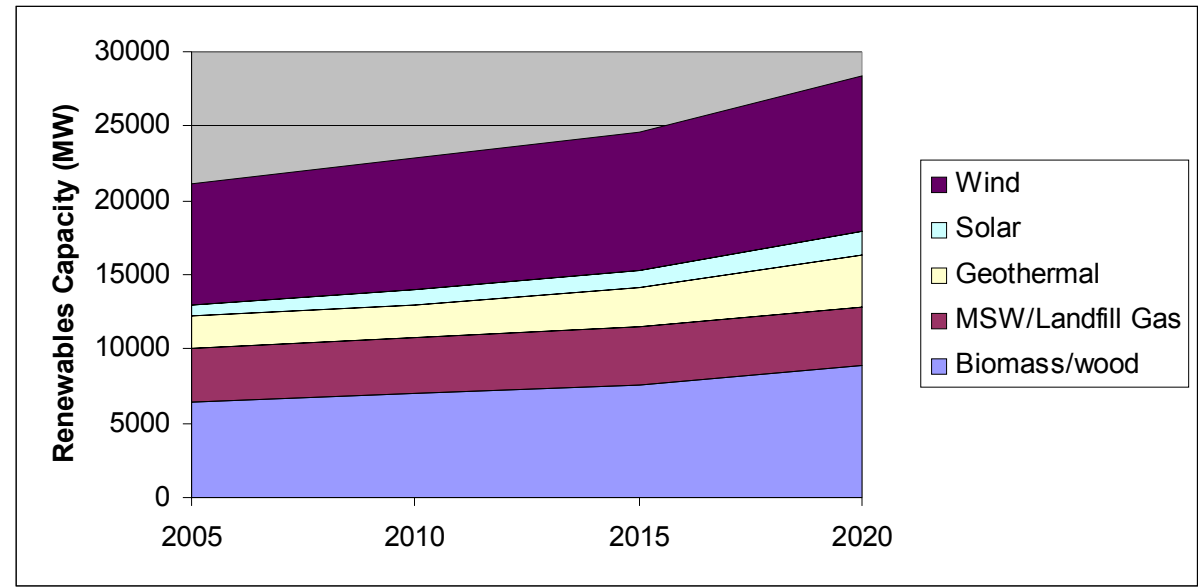

Figure 12. EIA Projection of Cumulative Renewable Capacity by 2020 2005 renewable energy projection is more conservative than its 2004 estimate, because of increased uncertainty regarding federal and state policy implementation. EIA research

${ }^{61}$ EIA Electric Sales and Revenue, 2002 http://www.eia.doe.gov/cneaf/electricity/esr/esr_sum.html

${ }^{62}$ EIA, 2005, p. 6.

${ }^{63}$ AEO, 2005 
has indicated that RPS implementation is proceeding at a slower rate than assumed under earlier projections. ${ }^{64}$ Therefore, its AEO 2005 projections assume that utilities do not fully comply with established RPS policies in future years. The projection assumes that the rest of the renewables capacity additions will be driven by commercially viable projects.

Other estimates offer more optimistic projections of renewable energy penetration. For example, Platts (2003) forecasts that renewable electric generating capacity will total $60,000 \mathrm{MW}$ by 2015 (five years earlier than the EIA projection); and will be driven mostly by RPS and, to a lesser extent, voluntary markets. ${ }^{65}$

Further, a number of other projections are based on individual market drivers, such as RPS policies, system benefits charges, voluntary markets, and IRP. Summing these independent forecasts yields a projection similar to Platts.

The Union of Concerned Scientists (UCS) estimates the new renewable energy generating capacity that will be needed to meet state renewable portfolio standards (RPS), and that will result from investments by state renewable energy funds. At the time we obtained the data, 18 states had adopted renewable portfolio standards and 15 states had established renewable energy funds, typically collected through a system benefits charge (SBC), or an adder on customers' electricity bills. By 2017, UCS estimates that 23,237 MW of new renewable capacity will be needed to meet existing state RPS policies, or 92.2 million $\mathrm{kWh}$. UCS assumes that SBC funds will not bring on any additional capacity, because most renewable energy projects that are supported through SBC funds are used to comply with RPS policies. Therefore, all of the capacity is attributed to the RPS, to prevent double-counting. ${ }^{66}$

Voluntary markets in which customers make voluntary purchases of renewable energy to match their own electricity consumption provide another market for renewable energy generation. A 2001 forecast by NREL and LBNL found that, by 2010, voluntary markets could support 596 average MW (aMW) of new renewables, or 5.2 million MWh annually, under a low-growth scenario and as much as 3,890 aMW (or 34.1 million MWh annually), under favorable market conditions (Table 3). The wide range of estimates of potential market size reflects the relatively immature nature of voluntary markets and the uncertainty surrounding issues such as the pace of restructuring (which was very uncertain at the time of the study), achievable market penetration rates, consumer access to green power, and the impact of green power marketing on supporting new renewables development. ${ }^{67}$ There is some potential for overlap between renewable energy used to meet RPS policies and that used to supply voluntary purchasers, but typically utilities and

\footnotetext{
${ }^{64}$ Petersick, 2004

${ }^{65}$ Platts, 2003. Renewable Power Outlook 2003, Platts Research \& Consulting Renewable Power Service, Boulder, CO, October.

${ }^{66}$ Union of Concerned Scientists, 2005. E-mail received from Jeff Deyette, February 5, 2005, containing estimates of renewables capacity planned under RPS policies through 2017.

${ }^{67}$ Wiser, R., M. Bolinger, E. Holt, and B. Swezey, 2001. Forecasting the Growth of Green Power Markets in the United States, NREL/TP-620-30101, LBNL-48611, October. http://www.eere.energy.gov/greenpower/resources/pdfs/30101.pdf
} 
marketers are careful to supply voluntary customers renewable energy above and beyond what is used to meet the RPS.

Table 3. Estimates of Renewables Development to Serve Green Power Markets (2010)

\begin{tabular}{|l|l|l|}
\hline & Low Growth (aMW) & High Growth (aMW) \\
\hline Existing Renewables & 309 & 3,082 \\
\hline New Renewables & 596 & 3,890 \\
\hline Total Renewables & 905 & 6,971 \\
\hline Source:
\end{tabular}

Source: Wiser et al 2001

Another driver for new renewable energy-generating capacity is the concept of Integrated Resource Planning (IRP). An IRP is defined as overall least-cost, long-term plan for a utility to meet its projected power needs. While the use of IRP declined during the movement toward restructuring, it is again becoming an important policy tool for developing renewables, particularly as wind generation has become more competitive with conventional generating technologies. Wiser (2005) collected data on renewable energy capacity planned through IRP for a number of large utilities in the West. Table 4 shows that just seven western utilities plan to add about 3,800 MW of renewable capacity by 2020 , according to their least-cost plans. ${ }^{68}$

Table 4. Renewable Capacity Planned Under IRP

\begin{tabular}{|l|r|}
\hline Utility & $\begin{array}{l}\text { Total IRP Additional } \\
\text { Capacity (MW) }\end{array}$ \\
\hline PacifiCorp & 1,420 \\
\hline Idaho Power & 450 \\
\hline Avista & 75 \\
\hline Portland General Electric & 195 \\
\hline Puget Sound Energy & 980 \\
\hline Northwestern & 150 \\
\hline PSCO & 500 \\
\hline Total & 3,770 \\
\hline
\end{tabular}

Source: Wiser (2005)

Summing the estimates of renewable energy market penetration resulting from RPS, state renewable energy funds, IRP, and voluntary markets yield about 35,000 MW of new renewable capacity additions by 2015 , bringing total renewable energy capacity to approximately 55,000 MW, which is generally consistent with the Platts estimate (Figure 13). We derived this estimate by using the average of the voluntary market high and lowgrowth scenarios for 2010, assuming 5\% annual growth through 2015. The original NREL/LBNL forecast used an annual growth rate of $7 \%$ for the low-growth scenario; thus, our assumed growth rate is intended to be conservative. The UCS and Wiser (2005) estimates are used directly. Although there is potential for overlap in these estimates (i.e., that some capacity will be brought online for IRP and used to meet an RPS), we do not account for any double-counting among the different studies. We believe this assumption

\footnotetext{
${ }^{68}$ Wiser, R., 2005. E-mail dated January 1, 2005, containing estimates of renewable capacity planned under Integrated Resource Planning.
} 
is reasonable, because generally sales of renewable energy to voluntary consumers are not counted toward RPS compliance. And, while projects brought online for IRP can often be sold into voluntary markets or used to meet an RPS, we have very limited data on IRP commitments, making the estimate very conservative, and most of the utilities listed in

Table 4 are not currently subject to an RPS.

Furthermore, this exercise is intended only to provide a rough estimate of future market penetration given current market conditions and

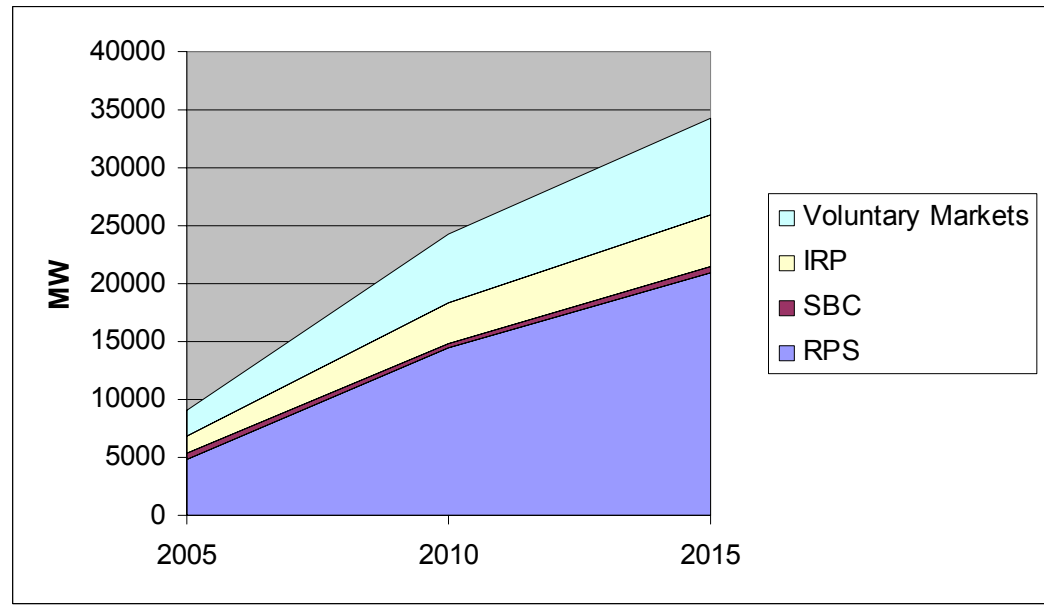

Figure 13. Estimated Renewable Capacity Additions by Key Driver, 2005 through 2015 drivers.

Using this approach, we find that, by $2015,61 \%$ of the new renewable energy capacity additions would be attributed to RPS policies, $24 \%$ to voluntary markets, $13 \%$ to IRP, and $2 \%$ to system benefits funds (UCS, 2005; Wiser et al. 2001; Wiser 2005) (Figure 13).

To provide some indication of the level of market penetration that could be achieved given favorable market conditions or increased support for clean energy technologies, we assume that the "technical potential" or maximum achievable penetration for renewables by 2020 is approximately $20 \%$ of total U.S. electric generating capacity. Although the true technical potential is larger, there is general consensus among industry participants that there may be significant challenges associated with integrating intermittent renewables, such as wind, into the grid at penetration levels beyond 20\%. Figure 14 compares our assumed maximum achievable renewables penetration of $20 \%$ with EIA's forecast of renewable

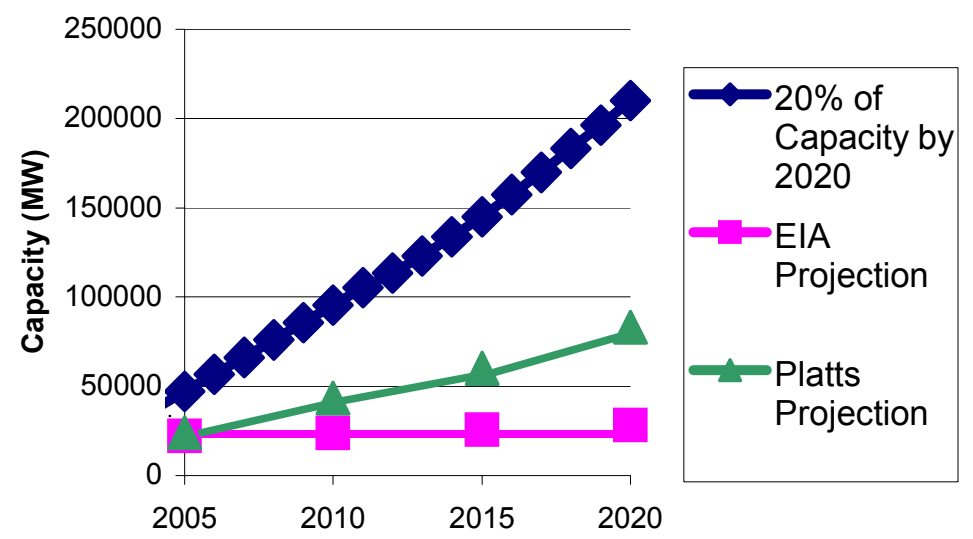

Figure 14. Market Forecasts for Renewables vs. $20 \%$ Penetration penetration by 2020 and the Platts forecast. WIP action in the clean-energy sector would likely lead to additional renewables above EIA's market forecast, but would not likely 
exceed the $20 \%$ threshold. Therefore, WIP action should be targeted to maximize its impact within these theoretical upper and lower bounds.

\section{$\underline{\text { Key Barriers to Renewable Resource Development }}$}

Of course, the ability for renewables to overcome current barriers will play a role in determining future market penetration levels. For example, lack of access to transmission is a key barrier to the development of many of the best renewable sites today. In addition, uncertainties related to short-term policies or ineffective policy implementation have affected renewable resource development. The most striking examples of this are the short-term extensions of the federal PTC, which has created a boom-bust cycle in the wind industry in recent years, and the inability of public utilities to use the Renewable Energy Production Incentive (REPI) for capital financing, because it is subject to annual congressional appropriations. Further, although RPS policies provide a long-term market for renewables, they have proven to be insufficient in some regions to encourage electricity providers to enter into long-term contracts for renewables. Other important barriers are the intermittency of some renewable energy sources, siting issues (such as bird and bat mortality and aesthetic issues for wind), interconnection obstacles, and the higher costs (or perceived costs) of some renewable energy technologies. And finally, there are information barriers, such as a lack of knowledge among states, utilities, and end-use consumers regarding the costs and benefits of renewable energy technologies. Future renewable energy penetration levels depend on the success of current efforts to address these barriers.

\section{Energy Efficiency in the Electric Sector}

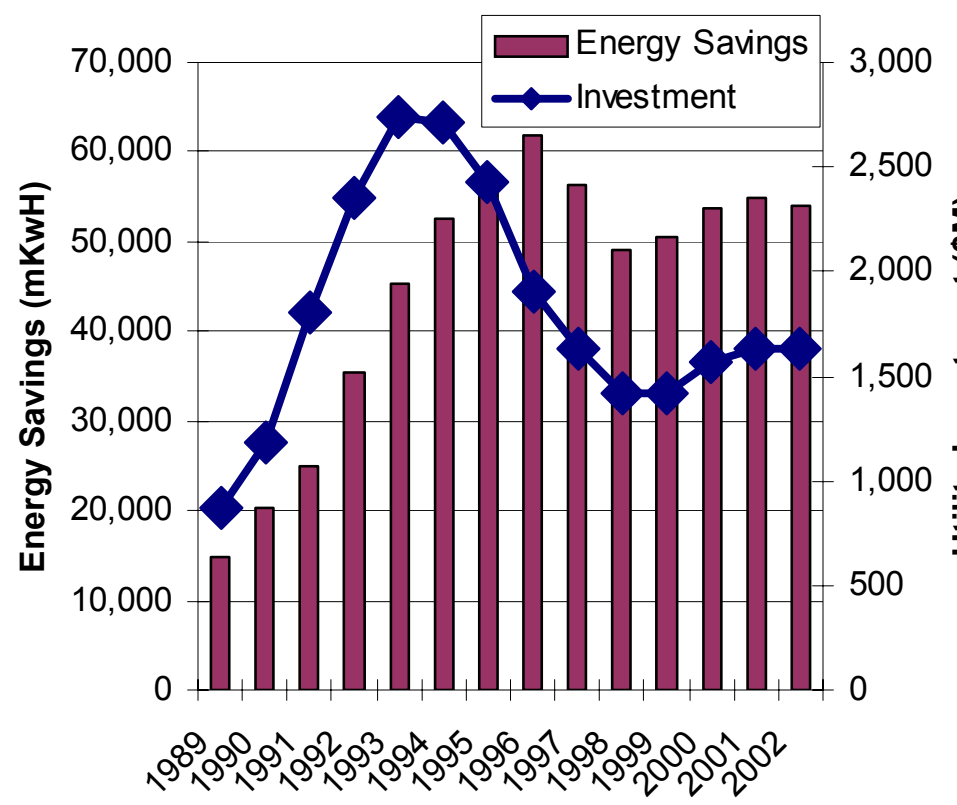

Source: EIA (2005)

Figure 15. Utility Investment and Energy Savings Resulting from Utility DSM Programs
With respect to energy efficiency in the electric sector, demand-side management (DSM) programs are used to curtail peak energy use, conserve natural resources, and delay transmission and distribution (T\&D) infrastructure investments. Included in these programs are energy efficiency measures such as home winterization and incentive programs for consumers to purchase more energyefficient appliances, as well as incentives for on-site generation of power. Because of the wide breadth of the energy efficiency measures, some 
of the resulting benefits from DSM are captured in the sectors toward which the programs are targeted: buildings or industrial.

In 1993, utility investment in DSM programs reached its peak and then began to decline, in part because of electric restructuring and the initiation of system benefits programs. However, the decreasing utility funding is not necessarily a reflection of decreasing demand-side electricity reduction program activity or impacts; rather, in some cases, it may be that utility investments were supplanted by investments by state system benefit funds. While annual savings peaked in 1996 (Figure 15), energy savings in subsequent years have still been significant, indicating program activity using alternate funding mechanisms.

Historically, IOUs made the largest investments in DSM programs. Table 5 shows utility investments in DSM by utility type Table 5. Utility Investment in DSM Measures, 2003 during 2003. IOUs were responsible for $78 \%$ of total DSM expenditures. ${ }^{69}$ While the largest opportunities for energy savings through DSM measures may exist at the IOU level, both public and cooperative utilities also offer opportunities. Municipal and cooperative utilities have been slow to participate in DSM programs, often because of limitations in staffing and budgets, resulting in extensive opportunities for energy efficiency improvements. Furthermore, municipal and cooperative utilities may be more open to DSM opportunities, because they do not have the same pressures that IOUs have to derive profits for their shareholders from the sale of electricity.

\section{Recent Investments by WIP and Others in Electric Sector}

In FY05, WIP invested $\$ 13$ million in renewable and clean-energy programs in the electricity sector under the Tribal Energy Program ( $\$ 5.5$ million), the Renewable Energy Production Incentive (\$5 million), and the State Energy Program (\$2.3 million). WIP investments were similar in previous years, totaling \$13 million in FY03 and \$11 million in FY04 (Table 6). In addition, a number of state, federal, and private-sector entities are making significant investments in the electric sector to develop clean and renewable energy sources.

\footnotetext{
${ }^{69}$ EIA-861 Form; * Primary energy savings based on 34\% average electric efficiency; ** Energy savings from all active DSM programs, including earlier years' activities ${ }^{70}$ Technology Roadmap: Energy Loss Reduction and Recovery in Industrial Energy Systems, prepared by Energetics, Inc. for the U.S. Department of Energy Office of Energy Efficiency and Renewable Energy Industrial Technology Programs, Draft
} 
For example, state renewable energy funds are currently investing about $\$ 300$ million annually in various forms of support for renewables. At the federal level, incentives such as the PTC, REPI, accelerated depreciation, and investment tax credits are available, as well as farm bill incentives ( $\$ 23$ million). Many states also offer incentives such as personal, sales, or property tax incentives. Private-sector investments include an estimated $\$ 2.8$ billion in capital and operation and maintenance expenditures in 2005 . While information is not available on all other Table 6. Electric Sector Investments in Renewables investments, Table 6 shows that private and other state/federal investments currently outweigh WIP investments by nearly 250 to 1 .

\begin{tabular}{|c|c|c|c|}
\hline & \multicolumn{3}{|c|}{$\$$ millions } \\
\hline & 2003 & 2004 & 2005 \\
\hline WIP Investments & $\$ 13$ & $\$ 11$ & $\$ 13$ \\
\hline Private Investments & $\$ 2,824$ & $\$ 1,423$ & $\$ 2,812$ \\
\hline Other State/Federal Investments & $\$ 335$ & 4335 & $\$ 335$ \\
\hline Total & $\$ 3,172$ & $\$ 1,769$ & $\$ 3,160$ \\
\hline Ratio Private a & $241: 1$ & 158:1 & 245: \\
\hline
\end{tabular}

A variety of organizations currently plays a role or makes investments in clean-energy markets or technologies (see Table 7).

Table 7. Key Market Actors/Potential Partners

\begin{tabular}{|l|l|}
\hline State and Regional & Private \\
Public utility commissions & Utilities \\
SBC funds administrators & Project developers \\
\cline { 2 - 2 } State energy offices & Federal \\
Governors/Western Governors Assoc. & FERC \\
RTOs & DOE Technology Programs \\
Northeast Regional Greenhouse & EPA Clean Energy Program \\
Gas Initiative & U.S. Department of Agriculture \\
\hline Nongovernmental Organizations & Consumers \\
& Residential and C\&I \\
\hline
\end{tabular}




\section{Industrial Sector Analysis}

\section{Approach and Methodology}

Because manufacturing represents, by far, the largest energy consumption in the industrial sector, this analysis will focus on U.S. manufacturing energy consumption. Savings in the remaining areas of the industrial sector are likely to be proportional (based on energy consumption).

The energy footprint provides a blueprint of the energy flows within industry and individual industrial sectors. ${ }^{70}$ The energy footprint shown in Figure 16 details the energy flows for the 24.7 quadrillion Btus (quads) of annual energy use associated with U.S. manufacturing (EIA 2004, EIA 2003). The total energy use shown in Figure 16 includes:

- On-site energy losses, i.e., the energy that is lost in energy systems from equipment inefficiencies, thermodynamic operating limitations, during distribution of energy throughout the plant, and in the conversion of energy to useful work; and

- Off-site losses, i.e., energy losses incurred off-site at the utilities providing the electricity and fuels that are purchased by the industrial sector. Off-site losses occur primarily in the generation and transmission of electricity.

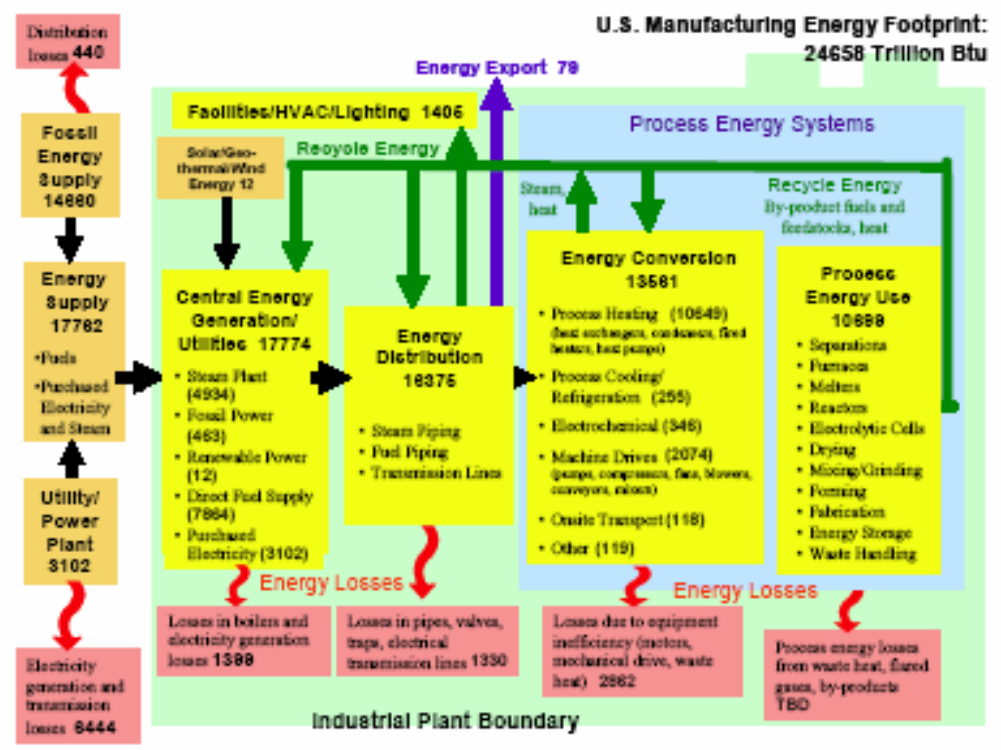

Figure 16. U.S. Manufacturing Energy Footprint (EI 2003)

The energy losses occurring on-site in manufacturing facilities represent immediate targets for energy efficiency improvements. As shown in Figure 16, of the 24.7 quads of energy used by manufacturing, approximately 5.5 quads $(22 \%)$ are lost within the industrial plant boundary prior to reaching the process. An additional $20 \%-50 \%$ of the energy finally delivered to processes can also be lost in the form of waste heat, flares, byproducts, and other sources. These downstream losses, which were not estimated for 
the footprint, are more complex and depend on the nature of the process and specific site conditions. In general, on-site energy losses can be reduced by adoption of more efficient technology, better integration of heat sinks and sources within the plant, increased utilization of waste energy, and improved operating and maintenance practices. Reduction of on-site losses has a compound effect, because less primary source energy is required to be produced.

ITP has successfully targeted on-site losses through its BestPractices program by using plant-wide assessments (PWA) and other tools and training programs targeting large facilities and through the Industrial Assessment Centers (IAC) for medium-size manufacturing facilities. Historical data from the BestPractices and IAC programs is used to establish a baseline of energy reduction opportunities.

\section{Sector Characteristics}

EERE's BestPractices program ( $\sim 88.5 \mathrm{M} / \mathrm{yr}$ DOE investment) for industrial plants classified as "large" (i.e., with annual energy costs greater than $\$ 2 \mathrm{M}$; Figure 17) has been shown to have a significant impact on industrial energy consumption and associated cost savings. Figure 18 shows that the 6,802 large-size plants account for $53 \%$ of energy consumed in U.S. manufacturing. Therefore, concentrated deployment efforts targeted at these relatively few plants will show a substantial return on investment per plant.

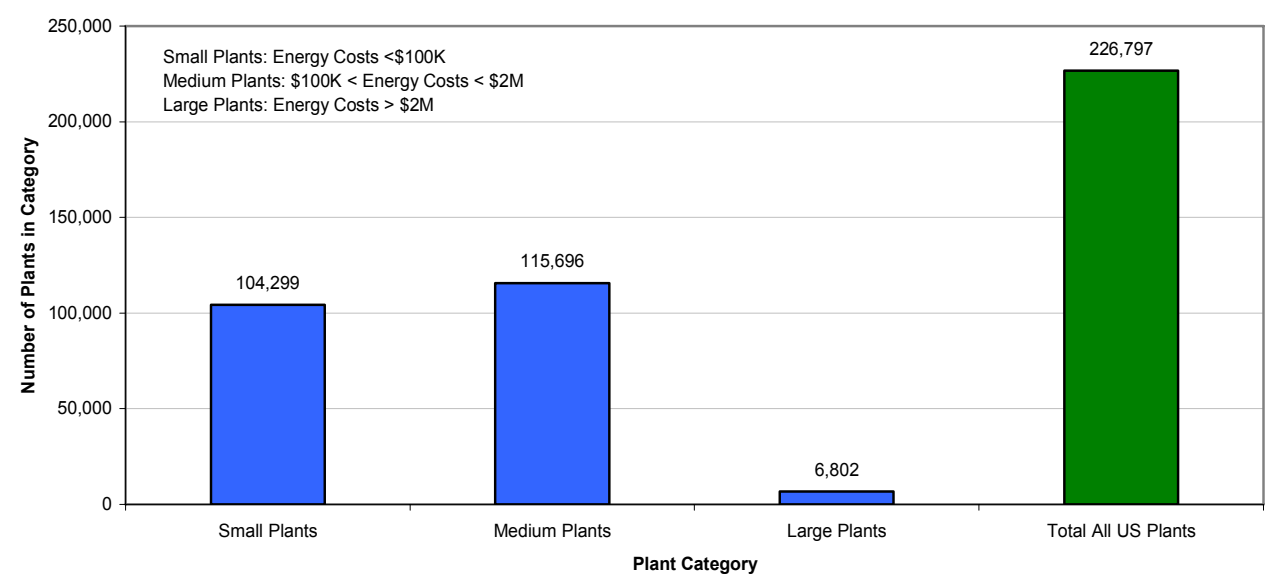

Source: ORNL analysis of 1998 MECS data

Figure 17. Number of U.S. Manufacturing Plants Within Energy Cost Categories 


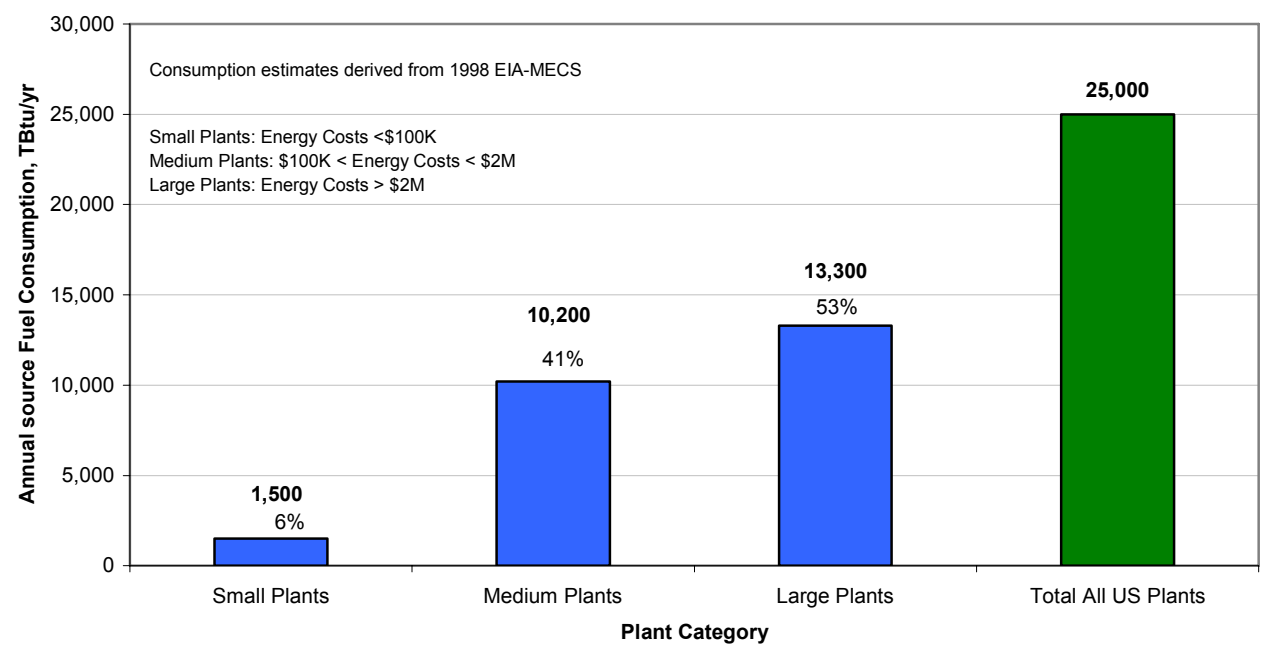

Source: ORNL analysis of 1998 MECS data

Figure 18. Total Energy Consumption for U.S. Manufacturing Plants by Energy Cost Category

Based on experience with approximately 50 PWAs of energy efficiency opportunities, ORNL has estimated that an average savings of $16 \%$ of a plant's annual energy costs can be achieved via deployment of existing technologies and best operating practices. In terms of potential industrial sector market impact, column 2 in Table 8 represents the low range of potential savings based on projected $16 \%$ PWA savings alone (i.e., additional savings attributed to other BestPractices tools/services not included). This estimate is based on 6,802 large-size plants with an average per plant energy consumption of 1,960 $\mathrm{BBtu} / \mathrm{yr}^{\mathrm{b}}$. If the BestPractices program were expanded to help reduce other on-site losses by one-half, column 3 in Table 8 represents an upper range of potential savings. These estimates assume a $100 \%$ market penetration.

Table 8. Estimated Impact for Large Plants at $100 \%$ Market Penetration

\begin{tabular}{|l|l|l|l|}
\hline & $\begin{array}{l}\text { (1) Impact Through } \\
\text { FY03 }^{11}\end{array}$ & $\begin{array}{l}\text { (2) Potential Industrial } \\
\text { Market Impact Based } \\
\text { on BP PWA Savings } \\
\text { Only }\end{array}$ & $\begin{array}{l}\text { (3) Potential Industrial } \\
\text { Market Impact Based } \\
\text { on BP PWA Savings + } \\
\text { Half of Other Onsite } \\
\text { Losses Saved }\end{array}$ \\
\hline TBtu/yr Savings & 200 & 2,132 & 3,599 \\
\hline
\end{tabular}

ITP's IAC program for "medium"-size plants (i.e., with annual energy costs greater than $\$ 100 \mathrm{~K}$ but less than $\$ 2 \mathrm{M}$; Figure 17) has also significantly contributed to industrial

\footnotetext{
${ }^{71}$ Source: ORNL analysis for ITP's annual Impacts report. Cumulative annual savings from BestPractices program inception in 1998 through 2003.

${ }^{72}$ Source: ORNL analysis of 1998 MECS data (see Figure 17)
} 
energy savings. Between assessments and the professional activities of the "army of energy engineers" generated by the program, the IAC program has resulted in cumulative industrial energy savings of 1,027 TBtu/yr over its 27-year life. DOE invests about $\$ 7 \mathrm{M} / \mathrm{yr}$ for the IAC program.

According to DOE, the average IAC assessment saves $\$ 55,000 .^{73}$ With average per plant energy consumption for medium-size plants of $88,000 \mathrm{MMBtu} / \mathrm{yr}^{\mathrm{b}}{ }^{\mathrm{b}}$ and assuming an energy cost of $\$ 5 / \mathrm{MMBtu}$, this results in an average $12.5 \%$ savings per assessment. If the IAC program were augmented with additional resources to help reduce other on-site losses by one-half, column 3 in Table 9 represents an upper range of potential savings. These estimates assume a 100\% market penetration. The 115,636 medium-size plants account for another $41 \%$ of overall manufacturing energy consumption, so additional efficiency improvement activities should be targeted at these plants, as well.

Table 9. Estimated Impact for Medium Plants at $\mathbf{1 0 0 \%}$ Market Penetration

\begin{tabular}{|l|c|c|c|}
\hline & $\begin{array}{l}\text { (1) IAC Impact } \\
\text { Through FY03 }\end{array}$ & $\begin{array}{l}\text { (2) Potential Industrial } \\
\text { Market Impact Based } \\
\text { on IAC Savings Only }\end{array}$ & $\begin{array}{l}\text { (3) Potential Industrial } \\
\text { Market Impact Based } \\
\text { on IAC Savings + Half } \\
\text { of Other Onsite } \\
\text { Losses Saved }\end{array}$ \\
\hline TBtu/yr Savings & 1,027 & 1,272 & 2,391 \\
\hline
\end{tabular}

The combined impacts for large and medium plants are given in Table 10, assuming a $100 \%$ market penetration.

Table 10. Estimated Impact for Medium and Large Plants at $\mathbf{1 0 0} \%$ Market Penetration

\begin{tabular}{|l|l|l|l|}
\hline & $\begin{array}{l}\text { (1) BP + IAC Impact } \\
\text { Through FY03 }\end{array}$ & $\begin{array}{l}\text { (2) Potential Industrial } \\
\text { Market Impact Based } \\
\text { on BP + IAC Savings } \\
\text { Only }\end{array}$ & $\begin{array}{l}\text { (3) Potential Industrial } \\
\text { Market Impact Based } \\
\text { on BP + IAC Savings } \\
\text { + Half of Other Onsite } \\
\text { Losses Saved }\end{array}$ \\
\hline TBtu/yr Savings & 1,227 & 3,404 & 5,990 \\
\hline
\end{tabular}

\section{Market Penetration}

To date, BestPractice's PWA activities have impacted about 60 plants $(<1 \%$ of the large plant population); IAC assessments have been conducted at slightly more than 13,000 plants (11\% of the medium-size plant population).

Follow-up studies have shown that, for most large plants participating in PWA activities, nearly $100 \%$ of the identified savings will eventually be captured. In addition, some large

\footnotetext{
${ }^{73}$ Source: www.oit.doe.gov/iac/

${ }^{74}$ Source: ORNL analysis of annual Impacts report. Cumulative annual savings from IAC inception in 1977 through 2003.

${ }^{75}$ Source: ORNL analysis for Impacts report.
} 
corporations have used PWA and training activities as impetus to establish in-house energy teams and have replicated activities at the majority of their facilities.

\section{Other Potential Industrial Areas for Reducing Energy Use}

\section{Water/Wastewater}

Nationally, water and wastewater systems have been estimated to account for up to $4 \%$ of total electricity demand ( $\sim 54$ to 75 billion $\mathrm{kWh} / \mathrm{yr}$ ) (EPRI, 2002). This load is expected to increase 20\% over the next 15 years (EPRI, 2004). In fact, as Table 11 shows, electricity use in the water/wastewater industry is on the same order of magnitude as the pulp and paper, chemical, and petroleum industries.

Table 11. Industrial Electricity-Use Comparison

\begin{tabular}{|l|r|}
\hline \multicolumn{1}{|c|}{ Industry } & Electricity Use (\% of total U.S. Load) \\
\hline Water/Wastewater & $\sim 3 \%$ \\
\hline Pulp and Paper & $\sim 3 \%$ \\
\hline Chemical & $\sim 6 \%$ \\
\hline Petroleum Refining & $\sim<2 \%$ \\
\hline
\end{tabular}

Source: DOE, 2004

Pumping costs to deliver the water supply to the customer comprise the largest component of energy use $(\sim 68-80 \%)$ in water/wastewater operations. Waste treatment comprises approximately $24 \%$ of energy use. The ITP BestPractices program already has tools and training in place to efficiently address pumping systems. DOE-sponsored targeted assessments and plant-wide assessments have shown that a $25 \%$ decrease in pumping system energy use is routinely achievable.

If this average energy savings is achieved at all water/wastewater plants, the potential energy savings of about 28 to 38 billion $\mathrm{kWh} / \mathrm{yr}$ (280 to 380 trillion Btu/yr of primary energy) could be attained. ITP BestPractices does not currently consider water/wastewater operations to be included in their targeted industries

\section{Industrial Buildings}

As indicated in the Buildings section of this document, energy use in industrial buildings accounts for almost 2 quads of energy use annually. The ITP BestPractices Program focuses exclusively on process and plant utility energy consumption and does not currently address the building aspects of energy consumption in the sector. Major opportunities exist in lighting, HVAC, and building shell areas. Based on the discussion in the Buildings section, an average savings of $10 \%$ is reasonably anticipated in this area.

\section{Mining}

Figure 19 shows that for NAICS code 212 (coal, metal ore, and nonmetallic mineral mining), total annual energy input is 1,273 trillion Btu (1.3 quads). Approximately 311 trillion Btu are lost within the mining operation boundary before reaching the process. An opportunity exists to reduce these on-site losses by one-half, annual savings of 156 trillion Btu could be achieved. 


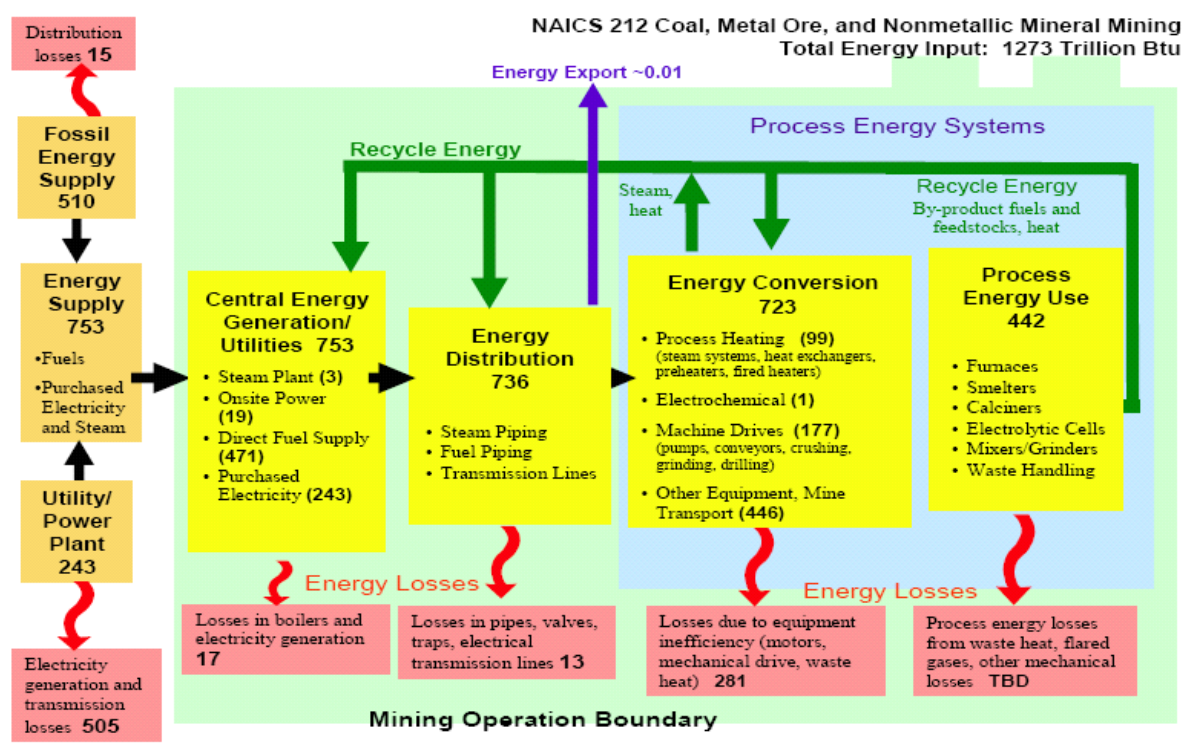

Source: DOE, 2004

Figure 19. NAICS Coal, Metal Ore, and Nonmetallic Mining Total Energy Input: 1,273 Trillion Btu

\section{Potential for Regional Activities}

U.S. energy consumption by state for the Industrial Sector is listed in Table 12. The table shows that $48 \%$ of all industrial energy consumption is accounted for in only seven states: Texas, Louisiana, California, Ohio, Indiana, Pennsylvania, and Illinois. Texas alone accounts for $20 \%$ of the U.S. industrial energy consumption. Targeted efforts in key states would be an efficient method of deployment. A $10 \%$ reduction in energy use in these top states would represent a potential 1,567 trillion Btu/yr in overall savings. 
Table 12. Industrial Sector Energy Consumption by State

\begin{tabular}{|c|c|}
\hline State & Trillion Btu \\
\hline Texas & $6,426.3$ \\
\hline Louisiana & $2,134.8$ \\
\hline California & $1,927.9$ \\
\hline Ohio & $1,428.9$ \\
\hline Indiana & $1,295.9$ \\
\hline Pennsylvania & $1,285.6$ \\
\hline Illinois & $1,173.4$ \\
\hline Michigan & 928.3 \\
\hline Georgia & 876.2 \\
\hline Alabama & 863.2 \\
\hline Kentucky & 845.9 \\
\hline Tennessee & 745.5 \\
\hline North Carolina & 743.2 \\
\hline Wisconsin & 728.5 \\
\hline New York & 667.4 \\
\hline South Carolina & 609.1 \\
\hline Florida & 598.2 \\
\hline Washington & 586.0 \\
\hline Virginia & 547.0 \\
\hline Oklahoma & 543.5 \\
\hline Minnesota & 526.1 \\
\hline New Jersey & 490.9 \\
\hline lowa & 472.3 \\
\hline Arkansas & 461.9 \\
\hline Mississippi & 427.3 \\
\hline Alaska & 412.5 \\
\hline Kansas & 384.8 \\
\hline Missouri & 374.3 \\
\hline West Virginia & 311.4 \\
\hline Oregon & 298.3 \\
\hline Colorado & 293.8 \\
\hline Massachusetts & 261.4 \\
\hline Maryland & 251.8 \\
\hline Wyoming & 238.1 \\
\hline Utah & 232.6 \\
\hline Arizona & 221.3 \\
\hline New Mexico & 219.5 \\
\hline North Dakota & 202.5 \\
\hline Maine & 198.8 \\
\hline Nebraska & 182.4 \\
\hline Idaho & 180.2 \\
\hline Nevada & 169.1 \\
\hline Connecticut & 133.6 \\
\hline Montana & 128.4 \\
\hline Delaware & 113.2 \\
\hline Hawaii & 76.7 \\
\hline New Hampshire & 68.3 \\
\hline South Dakota & 54.2 \\
\hline Vermont & 31.2 \\
\hline Rhode Island & 25.8 \\
\hline District of Columbia & 4.2 \\
\hline United States & $32,430.9$ \\
\hline
\end{tabular}

Source: EIA, 2001 


\section{Transportation Sector Analysis}

\section{Approach and Methodology}

The transportation sector comprises $27 \%$ of overall energy consumed in the United States (Figure 20), second only to the industrial sector. Because it is primarily a petroleum-based market, the transportation sector consumes nearly $70 \%$ percent of petroleum in the United States, ${ }^{76}$ lending itself to having the largest potential impacts on petroleum displacement. The purpose of this analysis is to identify those displacement opportunities and outline the potential for petroleum reductions in the transportation sector.

The objective of this summary is to describe the

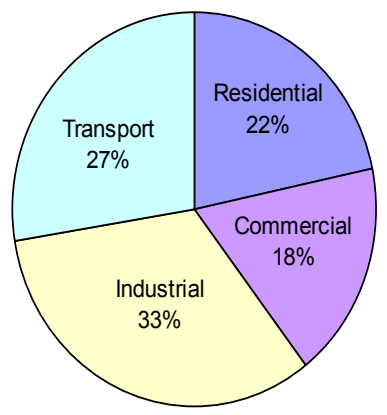
transportation market, and identify opportunities for government to reduce petroleum consumption in the transportation sector. The first section outlines the market and identifies the most petroleum-intensive transportation subsectors, as well as summarizes the projections of future petroleum use. The second section describes the key end-use market segments and reviews the market drivers and barriers related to those segments.

Understanding the transportation market is a challenge because of the diversity of the market, as well as the diversity of data sources tracking the market. The variety of vehicles in the sector makes accurately estimating the average petroleum use per vehicle difficult, and an average with such high variation has limited usefulness in effective program design. As a result, research in this area has organically grown to focus on a number of smaller market segments such as light-duty vehicles or heavy-duty vehicles. Adding to the challenge of outlining the market is that some bodies of research concentrate only on a particular end-use segment, as in the case of research that focuses only on light-duty vehicles or on diesel-fueled vehicles, which make cross-sector comparisons difficult. The following market analysis synthesizes a large volume of available resources, including federal and state government, nonprofit, and private-sector data and research ${ }^{77}$ - all in an effort to create a comprehensive market description that defines market segments based on common petroleum-use characteristics.

Following the market synopsis section, we analyze the potential for petroleum reduction in the transportation sector by market segment. This includes a discussion of market barriers to reducing petroleum use and the previous and potential role of government and other entities in lowering those barriers.

\footnotetext{
${ }^{76}$ Energy Information Administration (EIA), Department of Energy (DOE). 2005. Annual Energy Review 2003. DOE/EIA-0384(2003)

${ }^{77}$ Resources include the Energy Information Administration, state energy offices, Natural Resources Canada, and the 2004 Automotive Fleet Fact Book. Specific references to resources are noted in the text.
} 
Overall, this analysis suggests opportunities in the transportation sector for improving energy efficiency and alternative-fuel use through consumer (personal vehicle) and corporate (fleet) information transfer, and the encouragement of local and state programs to voluntarily adopt mandates for increasing market penetration. Results of the benefits analysis show that government programs targeting these areas could have a significant impact on increasing market penetration with in the identified client groups. Future research into potential benefits would allow for refining the proposed programs and more accurate benefits estimation.

\section{Sector Characteristics}

\section{Market Synopsis}

In 2002, the transportation sector accounted for more than 26 quadrillion Btus or $27 \%$ of total energy consumption (Figure 20). Highway transportation accounted for $81 \%$ of transportation energy use, including light-, medium-, and heavy-duty vehicles as well as buses. The remaining energy use is primarily split between air and water transport (Figure 21). ${ }^{78}$

Light-duty vehicles (cars and light trucks) made up about $75 \%$ of highway fuel consumption, or

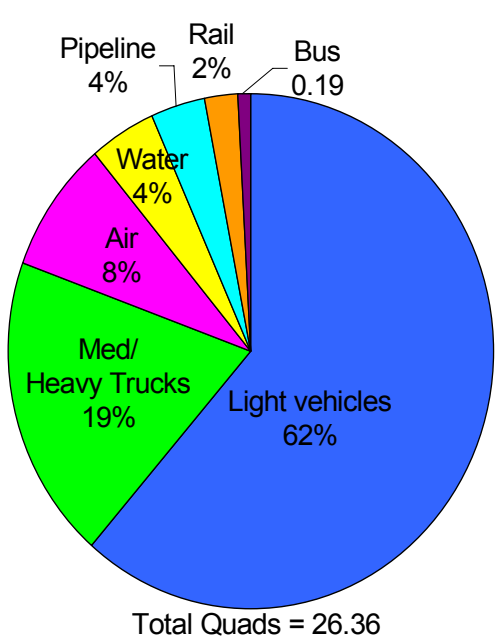

Source: Transportation Energy Data Book: Edition 24, 2004, Table 2.5

Figure 21. Transportation Energy Use by Mode 16 total quads. ${ }^{79}$ The 200 million light-duty vehicles account for the greatest proportion of transportation fuel use (Figure 22). The primary fuel of light-duty vehicles was gasoline, although more than 3 million - alternative fuel vehicles (AFVs) - are equipped to use alternative fuels, Of these AFVs, $99 \%$ are flexible fuel vehicles, meaning gasoline or the alternative fuel can be used for fuel. The remaining $1 \%$ are dedicated AFVs, only configured to use the alternative fuel.

The actual use of alternative fuels in vehicles is difficult to determine because of the majority of flex-fuel AFVs. Averaging the use of alternative fuels over the entirety of the fleet is also limited by regional differences in fuel infrastructure, availability, and price. As a result of these difficulties, alternative-fuel use is generally measured by alternativefuel sales, not actual usage per vehicle. In 2002, liquefied petroleum gas (LPG) and

\footnotetext{
${ }^{78}$ Energy Information Administration, Department of Energy. 2005. Annual Energy Outlook 2005 with Projections to 2025. DOE/EIA-0383(2005). Table 7.

${ }^{79}$ Light-duty vehicles account for almost 16 quads out of almost 21 total quads of highway transportation energy consumption. Energy Information Administration, Department of Energy. 2005. Annual Energy Outlook 2005 with Projections to 2025. DOE/EIA-0383(2005)).
} 
compressed natural gas (CNG), dominated the alternative-fuel market making up 47\% and $46 \%$, respectively. ${ }^{80} \mathrm{~A}$ further trend is the growth of electricity as an alternative vehicle fuel in the years leading up to 2002 (Figure 23). ${ }^{81}$

Future use of alternative fuels is projected by the Energy Information Administration (EIA) in the Annual Energy Outlook (AEO). ${ }^{82}$ The projections are largely dependent on a set of assumptions about the future of the AFV market and infrastructure for alternative-fuel delivery systems. The assumptions that have the largest potential to change the projections are those associated with the Energy Policy Act of 1992 (EPAct), which (among other things) requires that certain fleets increase their amount of annual purchases of AFVs (further discussed in the fleet-specific market review below). The EIA projections assume no change in the EPAct through 2025, and a constant share of sales for alternative vehicles based on 2000 sales. For non-fleet purchases, EIA assumes that consumers will choose vehicles based on fuel type and availability, and then within the broader set of vehicle attributes (such as price, maintenance costs, and battery replacement). ${ }^{83}$ Based on these assumptions, projections for light-duty vehicle alternativefuel consumption show continued

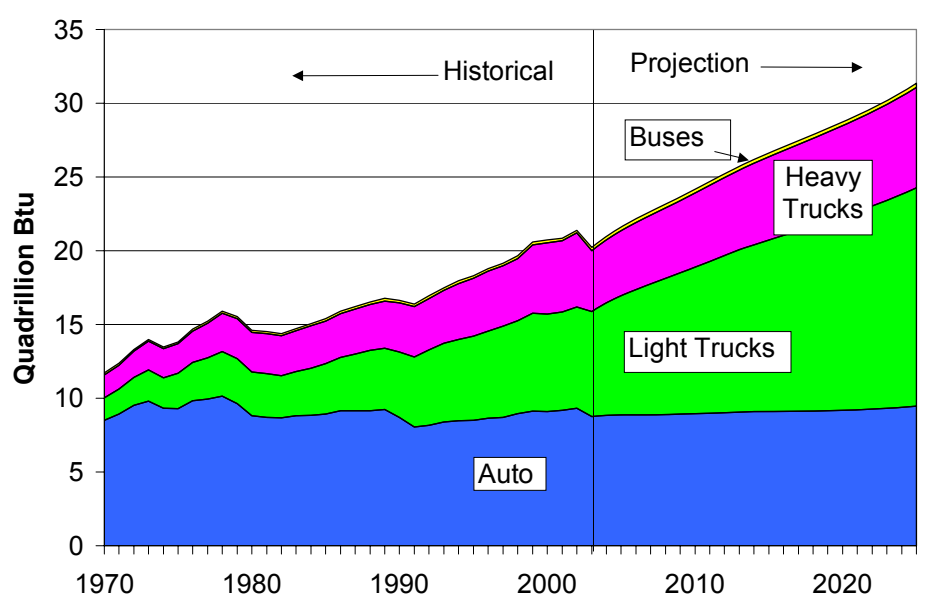

Sources: EIA. Historical - Annual Energy Review 2003, Projection - AEO 2004

Figure 22. Highway Transportation Energy Consumption by Mode

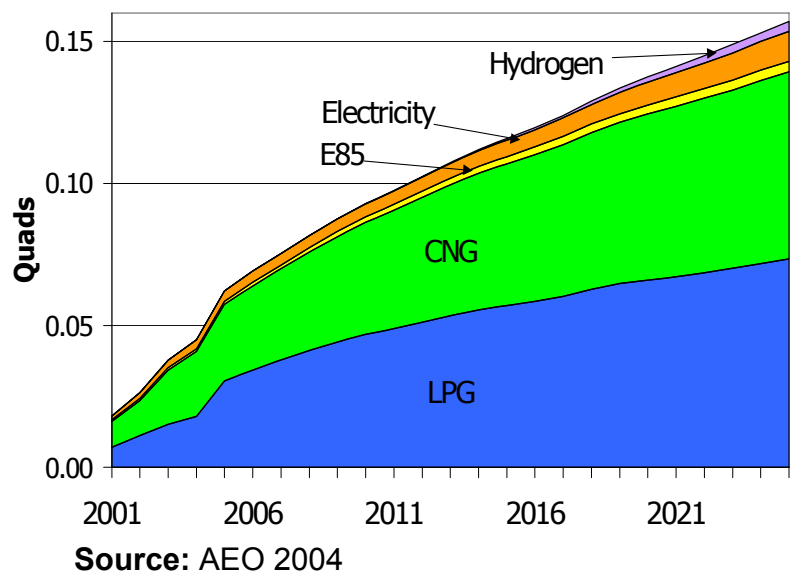

Figure 23. Projected Growth in Alternative Fuels for the Transportation Sector

${ }^{80}$ Energy Information Administration, Department of Energy. 2005. Annual Energy Outlook 2005 with

Projections to 2025. DOE/EIA-0383(2005). Supplemental

${ }^{81}$ EIA Annual Energy Review 2003. Table 10.7

${ }^{82}$ Energy Information Administration, Department of Energy. 2005. Annual Energy Outlook 2005 with Projections to 2025. DOE/EIA-0383(2005). Supplemental Table 46.

${ }^{83}$ For more detailed assumptions, see EIA. 2005. Assumptions to the Annual Energy Outlook 2005. 
growth $^{84}$ for CNG and LPG, while electricity comes on in later years. Total alternativefuel use is projected to increase from $0.16 \%$ of the light-duty vehicle market to $0.66 \%$ between 2002 and $2025 .{ }^{85}$

Medium- and heavy-duty vehicles are defined as those highway vehicles weighing more than 10,000 pounds. Diesel fuel is the dominant fuel in this market, comprising $94 \%$ of total use. Gasoline, LPG, and CNG are also used, making up 5\%, $0.2 \%$, and $0.05 \%$ of the market, respectively. EIA projects changes in the heavy-duty alternative-fuel vehicle market, primarily assuming changes to federal environmental laws regulating air and particulate emissions. ${ }^{86}$ This methodology leads to an increase in alternative (nonpetroleum) fuels in the medium- and heavy-duty transportation sectors overall to $0.88 \%$, with CNG being the primary alternative fuel at $0.69 \%$ of the market. ${ }^{87}$

\section{Investments in the Transportation Sector}

Increasing market share of nonconventional vehicles involves a combination of public and private investment in technology development and consumer education and understanding. Two primary difficulties exist in the categorization and quantification of publicly and privately funded programs in the transportation sector. The first is that the designers of the various programs have differing priorities and, therefore, the focus of the program and the available measures of success vary. This, combined with the highly competitive nature of the automobile industry - which limits access to development and R\&D investment information - make identifying the current level of funding for increasing market share of alternative-fuel vehicles challenging. A primary role of the private sector is largely to meet or exceed customer expectations profitably, including the use of new technologies for improved performance, fuel economy, and price/value. While deployment and marketing are also important aspects of automotive investment in advanced technology, information on investments made by industry in specific vehicletypes (AFVs, for example) is very limited, and therefore useful information is not readily available.

The opportunities for energy efficiency improvement and alternative-fuel vehicles in this sector are heavily weighted toward consumer education, where there is some data on previous investments from the governmental and nonprofit sector. The Department of Energy's (DOE) Office of Energy Efficiency and Renewable Energy (EERE) incorporated the goal of increasing market share for advanced vehicle technology and deployment in many of its programs, including the Hydrogen, Fuel Cells, and Infrastructure Program and the FreedomCAR and Vehicle Technologies Program. Programs focusing primarily on deployment include those housed within the

\footnotetext{
${ }^{84}$ Energy Information Administration, Department of Energy. 2005. Annual Energy Outlook 2005 with Projections to 2025. DOE/EIA-0383(2005). Supplemental Table 34

${ }^{85}$ Energy Information Administration, Department of Energy. 2005. Annual Energy Outlook 2005 with Projections to 2025. DOE/EIA-0383(2005). Electricity includes electricity used by electric vehicles, but not electricity used by hybrid (diesel or gas) vehicles.

${ }^{86}$ For more detailed assumptions, see EIA. 2005. Assumptions to the Annual Energy Outlook 2005.

${ }^{87}$ Energy Information Administration, Department of Energy. 2005. Annual Energy Outlook 2005 with Projections to 2025. DOE/EIA-0383(2005). Supplemental Table 34.
} 
Weatherization and Intergovernmental Program (WIP), including the Clean Cities ${ }^{88}$ and State Partnership grants for increasing market share of advanced technology. The investment that WIP makes in these two programs was approximately \$11 million in Clean Cities and \$4 million in State Partnership grants in 2004. This funding leverages almost $100 \%$ of its value in matching private and state and local government funds. Another program focusing on consumer education and information transfer is the Fuel Economy Guide Program, the centerpiece of which is a Web site allowing consumers to review the benefits of increased fuel economy and other attributes of vehicles. The program invests $\$ 700,000$ in the information program and reports savings of more than 65 million gallons of gasoline annually. ${ }^{89}$

\section{Key Segments in the Light-Duty Transportation Market}

\section{Personal-Vehicle Market}

\section{Market Description}

Generally, data and information presented on the light-duty vehicle market does not differentiate between personal vehicles and fleet vehicles. For the purposes of designing WIP programs, however, this analysis needs to separate the fleet from the personal vehicle market to understand the needs of the market in terms of the key end-use market segments. Market data indicates that $95.6 \%$ of the total U.S. vehicle stock is comprised of personally owned vehicles. ${ }^{90}$ Because personal vehicles are, on average, driven less than average fleet-owned vehicles, the personal vehicle market accounts for a disproportionately smaller $90 \%$ of light-duty vehicle fuel consumed. ${ }^{91}$ The structure of this description of the personal-vehicle market, unless otherwise noted, reflects the data collected for all light-duty highway vehicles, less the portion of the market assumed to be fleet-related.

The personal-vehicle market accounts for approximately $65 \%$ of highway fuel consumption $^{92}$ and almost $48 \%$ of overall transportation energy consumption. ${ }^{93}$ There

\footnotetext{
${ }^{88}$ Following completion of this analysis in FY05, the Clean Cities activity was moved to EERE's FreedomCAR and Vehicle Technologies Program in FY06.

${ }^{89}$ Taylor, K. 2005. (CTTS). Personal Communication to Elizabeth Brown via Ron Benioff. April 14, 2005.

${ }^{90}$ There were 9 million light-duty fleet vehicles (Transportation Energy Data Book, Edition 24, 2004) out of a total of 208 million light-duty vehicles. Energy Information Administration, Department of Energy. 2004. Annual Energy Outlook 2004 with Projections to 2025. DOE/EIA-0383(2004).

${ }^{91}$ Light-duty fleet vehicles account for 1.6 quadrillion Btu of energy consumption out of a total of 15.583 quadrillion Btu light-duty vehicle consumption. Energy Information Administration, Department of Energy. 2004. Annual Energy Outlook 2004 with Projections to 2025. DOE/EIA-0383(2004). Table 50. ${ }^{92}$ Light-duty vehicles consume 15,583 quadrillion Btus (75\%) of energy out of 20,792 total highway consumption in 2002. Energy Information Administration, Department of Energy. 2005. Annual Energy Outlook 2005 with Projections to 2025. DOE/EIA-0383(2005). Sixty-five percent reflects the $14 \%$ that is attributable to fleets. Highway Use is defined as not air, water, pipeline and rail transport.

${ }^{93}$ Light-duty vehicles consume 15,583 quadrillion Btus (58\% ) of energy out of 26,922 total highway consumption in 2002. Energy Information Administration, Department of Energy. 2005. Annual Energy Outlook 2005 with Projections to 2025. DOE/EIA-0383(2005). Forty-eight percent reflects the $14 \%$ that is attributable to fleets.
} 
were 194 million personal light-duty vehicles on the road ${ }^{94}$ in 2002 and 15.3 million new personal vehicles sold. ${ }^{95}$ Of these vehicles, 189 million were conventional gasoline fueled vehicles. ${ }^{96}$

In 2001, more than $92 \%$ of households had at least one vehicle. The average number of vehicles per household was 1.9. Daily trips, primarily to work or school, averaged 14,500 miles per person per year in 2001. The working-age (25-64) population averaged the largest amount of vehicle trips per day at 4.6. A total of $86 \%$ of those trips were taken in a personal vehicle. ${ }^{97}$

\section{Projected Trends}

According to the Energy Information Administration (EIA), personal vehicle sales show a movement toward more light trucks over cars in general, but with nonconventional ${ }^{98}$ technology vehicles reaching $2 \%$ of new vehicle sales by 2025 . For the EIA estimates, gains in nonconventional technology vehicles result from high gas prices relative to other fuels, increasing cost-effectiveness for the manufacturer to produce the vehicle, and a variety of performance features integrated into the Transportation Demand Model of NEMS. ${ }^{99}$

EIA estimates may be conservative, however, in terms of the increased market penetration of hybrid-technology vehicles. Recent new-vehicle sales numbers released by manufacturers have led to different projections stemming from the private sector. Sales of hybrid vehicles doubled between January 2004 and January 2005, and tripled between April 2004 and 2005. ${ }^{100}$ The overall sales of hybrid vehicles increased $81 \%$ between 2003 and 2004. ${ }^{101}$ Assuming that hybrid sales consistently increase by a third of that, or $25 \%$, between 2005 and 2025, the market share for hybrids could increase to $16 \%$ of new car sales by 2025 , well above the EIA projected $2 \%$.

\footnotetext{
${ }^{94}$ Two hundred three million total light-duty vehicles in stock in 2002 , less $4.4 \%$ attributable to fleets. Energy Information Administration, Department of Energy. 2004. Annual Energy Outlook 2004 with Projections to 2025. DOE/EIA-0383(2004). Table 45.

${ }^{95}$ Sixteen million total light-duty vehicles sold in 2002, less $4.4 \%$ attributable to fleets. Energy Information Administration, Department of Energy. 2004. Annual Energy Outlook 2004 with Projections to 2025. DOE/EIA-0383(2004) Table 45.

${ }^{96} \mathrm{http}: / /$ www.eia.doe.gov/oiaf/aeo/supplement/suptab_46.xls

${ }^{97}$ Bureau of Transportation Statistics. 2003. Highlights of the 2001 National Household Transportation Survey. BTS: Washington, D.C.

${ }^{98}$ Hybrid and alternative-fuel vehicle.

${ }^{99}$ EIA 2005. Major Assumptions of the Annual Energy Outlook 2003. http://www.eia.doe.gov/oiaf/aeo/assumption/pdf/0554(2005).pdf

${ }^{100}$ R.L. Polk http://www.polk.com/

${ }^{101} \mathrm{http}: / /$ www.gm.com
} 
The EIA projection of $2 \%$ market penetration falls a full percentage point under a J.D. Power and Associates projection of 3\% by 2010 (Figure 24). The J.D. Power and Associates projection levels off after 2010 due to their assumption that conventional vehicle technology will improve to compete with the projected popularity of hybrids. ${ }^{102}$ A 2004 Booz Allen Hamilton report projects a much larger share of the sales market to be saturated by hybrids, at $20 \%$ by 2010 and $80 \%$ by $2015 .{ }^{103}$ Figure 24 shows the range of these different projections of new vehicle sales, with the EIA projection being lowest.

Changes in vehicle stock, however, require longer-term consumer choice changes because of the slow growth and turnover of vehicle stock. ${ }^{104}$ To illustrate the turnover in the market, Figure 25 shows the EIA projections for vehicle sales by technology type, and Figure 26 shows the resulting change in overall stock composition, and includes the projected impact of the increasing market for conventional light trucks. While the EIA numbers for hybrid growth are likely

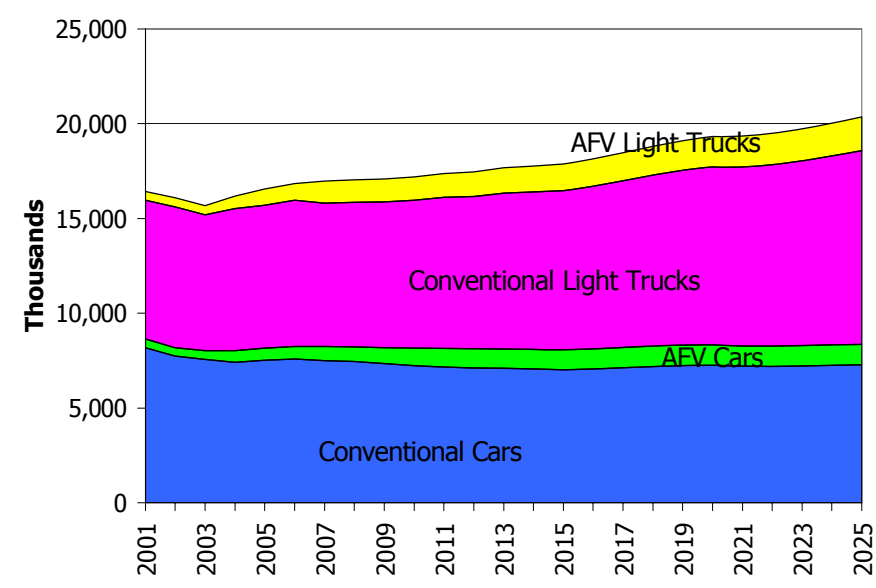

Source: AEO 2004

Figure 25. New Vehicle Sales by Technology Type

conservative as discussed above, the stock makeup projections are useful to show the complicated nature of the market and the length of time required to make changes to the market due to the long life cycle of vehicles.

\footnotetext{
$102 \mathrm{http}: / /$ www.jdpower.com/news/releases/pressrelease.asp?ID=2005013

${ }^{103} \mathrm{http}: / /$ www.businessweek.com/magazine/content/04 44/b3906051 mz011.htm

${ }_{104}$ David Greene spreadsheet assumption
} 


\section{Consumer Market Drivers and Barriers}

The foremost market drivers for increasing vehicle efficiency and nonconventional vehicles in the consumer transportation sector are increasing fuel prices and increasing fuel price volatility. EIA data reflect seasonal volatility in gasoline prices. ${ }^{105}$ The longerterm energy outlook incorporates price volatility and increases resulting from domestic policies and changes in distribution costs, but does not account for decreasing supply (real or artificial) over time. ${ }^{106}$ Current and future political unrest in major petroleumproducing regions may have impacts on gasoline price and volatility not reflected by the DOE estimates. These uncertainties are the largest drivers for changes in petroleum consumption. Hybrids and alternativefuel vehicles may appeal to the consumer as a way to alleviate gasoline price uncertainty as evidenced by the increasing demand for hybrid vehicles.

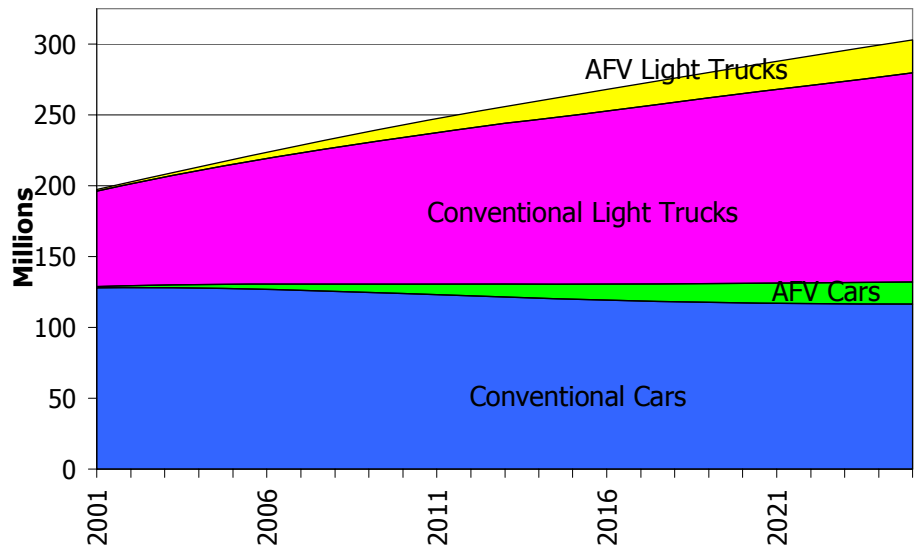

Source: AEO 2004

Figure 26. Total U.S. Vehicle Stock Projection

Canadian research shows that given level incentives and taxes, and removing the need for increased infrastructure, the cost of most alternative fuels is equal to or lower than gasoline-powered vehicles. ${ }^{107}$ Disproportionate fuel incentives and the high cost of fuel infrastructure are reflected in the real cost of fuels - that cost seen by consumers - and represent significant barriers to integration of alternative-fuel vehicles into the market. In addition, technical challenges still exist in the alternative-fuel market, as distance range and weight issues are being worked out for a variety of technologies. ${ }^{108}$ Finally, in the case of hybrids, consumers may not account for the life-cycle costs of the vehicle, leading to undervaluing the efficiency of the technology. ${ }^{109}$

\footnotetext{
${ }^{105}$ Monthly Energy Review, EIA

${ }^{106}$ EIA assumptions (petroleum module)

${ }^{107}$ NRCAN

http://www.nrcan.gc.ca/es/etb/cetc/cetc01/htmldocs/factsheet_transportation_energy_technologies program_e.html

${ }^{108}$ Hydrogen and compressed natural gas, specifically.

${ }^{109}$ Flynn, Peter, 2002. Commercializing an alternate fuel vehicle: lessons learned from natural gas for vehicles.
} 


\section{Fleet Market}

\section{Market Description}

The fleet market of light-duty vehicles consisted of almost 9 million vehicles in 2003 (4.4\%) of the light-duty vehicle market. ${ }^{110}$ Light-duty fleet vehicles accounted for about 1.6 quadrillion Btus of energy consumption $(10 \%)$ of total light-duty consumption. ${ }^{111}$ The top light-duty fleet manufacturers in terms of number of cars are GM, Ford, and Chrysler. ${ }^{112}$ Car fleets are used for business, rental cars, government and police, and taxi; while light-duty truck fleets are primarily business and government.

Medium- and heavy-duty fleet trucks consume 2.5 quadrillion Btu of energy (about $60 \%$ ) of mediumand heavy-duty fuel use. ${ }^{113}$ Four industries dominate medium- and heavy-duty fuel use: for-hire transportation and warehousing, construction, wholesale, and retail. Figure 27 shows the EIA projections for future fleet petroleum use.

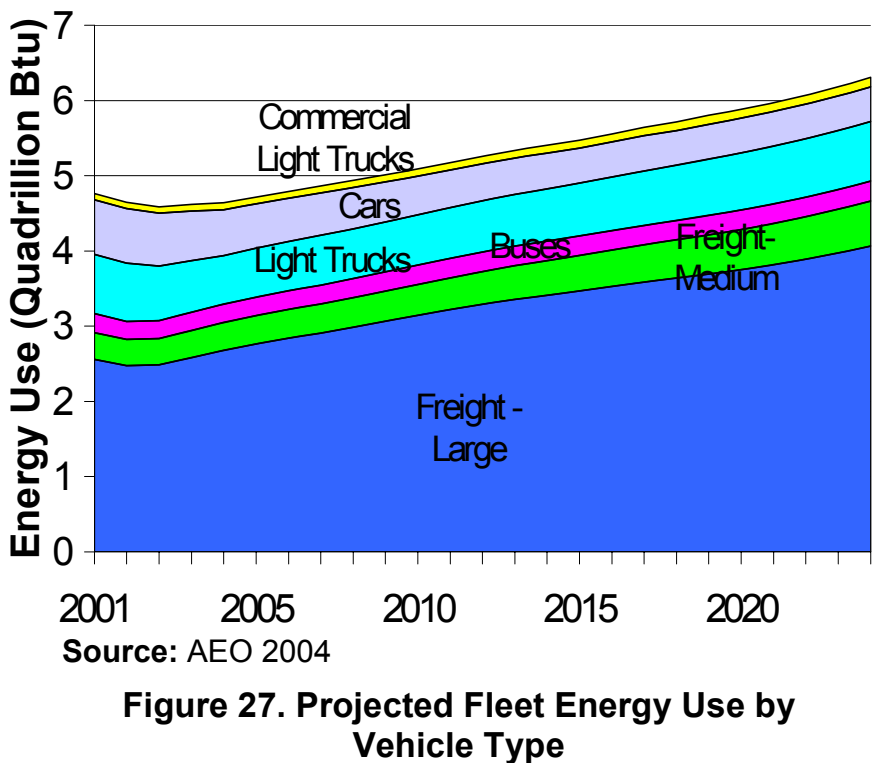

The light-duty fleet market can be divided into two primary market segments as a result of the Energy Policy Act of 1992 (EPAct): EPAct and Non-EPAct fleets. This act requires certain governmental fleets to purchase an increasing percent of their overall new-vehicle acquisitions as alternative-fuel vehicles. Fleets that must comply with EPAct include federal and state non-emergency government fleets comprised of more than 20 light-duty vehicles. EPAct-regulated fleets are already mandated to comply with particular alternative-fuel requirements and, thus, fall outside the scope of this analysis.

Fleets that are not covered by EPAct can be further segmented by organizational structure and decision-making behavior. The largest subsegment is corporate-owned fleets,

\footnotetext{
${ }^{110}$ Davis, S. and S. Diegal. 2004. Transportation Energy Data Book, Edition 24. ORNL-6973. ORNL: Oak Ridge, Tennessee.

${ }^{111}$ Energy Information Administration, Department of Energy. 2005. Annual Energy Outlook 2005 with Projections to 2025. DOE/EIA-0383(2005). Light-duty fleets consume 1.6 quadrillion Btus out of a total of 15.583 for light-duty vehicle consumption.

${ }^{112}$ Source: Automotive Fleet Factbook, 2004.

${ }^{113}$ Energy Information Administration, Department of Energy. 2005. Annual Energy Outlook 2005 with Projections to 2025. DOE/EIA-0383(2005).
} 
comprising $50 \%$ of the fleet market. ${ }^{114}$ A smaller subsegment is state and local government fleets that are not required to comply with EPAct ("non-EPAct government") and institutional fleets, which account for a combined $10 \%$ of the market. ${ }^{115}$ Fleetpurchasing structure lends itself to programmatic targeting because of the opportunity to impact a large number of vehicles - an entire fleet - through one point of contact, which has potentially large effects on petroleum consumption. The market drivers and barriers differ across the two subsegments, but the decision-making criteria within each segment is well-defined, which makes it easier to structure a focused program. More detailed market information for these two types of fleets follows in the next two sections.

\section{Corporate Fleets}

Medium to large corporate fleets comprise roughly $50 \%$ of the fleet market. Thirteen companies account for $2.5 \%$ of the fleet market in terms of number of vehicles (Figure 28). ${ }^{116}$ Factors that drive corporate fleet marketpurchasing decisions range from economic to image considerations. ${ }^{117}$ Corporate fleet managers and decisionmakers tend to be proactive, fiscally minded, and image conscious. Corporate fleet

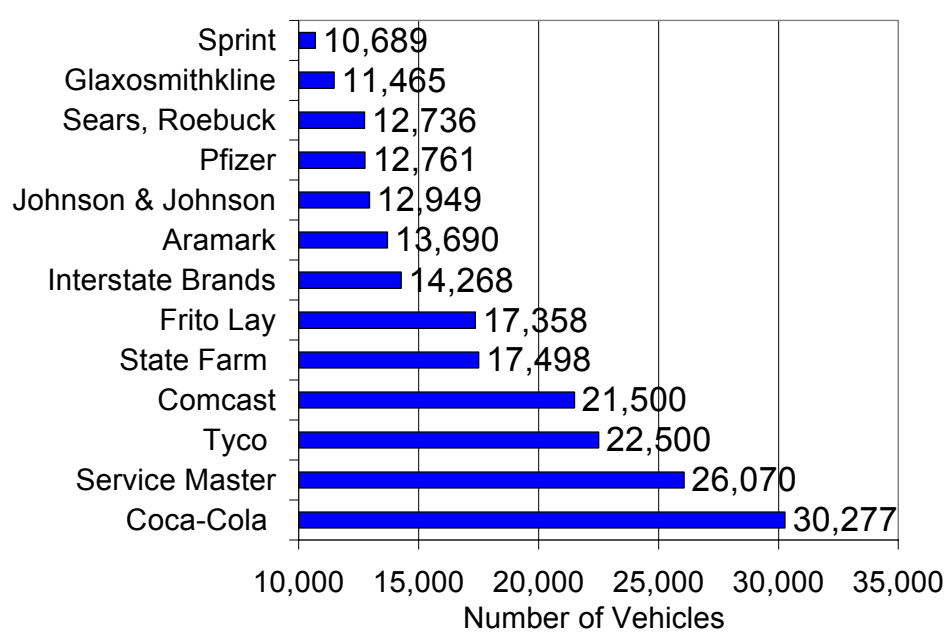

Source: Automotive Fleet Fact Book: Edition 24, 2004

Figure 28. Large U.S. Corporate Fleets managers also tend to favor longer-term solutions and are driven by incentives, subsidies, and tax breaks.

The market barriers to purchasing alternative fuel vehicles and hybrids by corporate fleets fall primarily under infrastructure constraints and cost. Two infrastructure considerations are fuel and vehicle service availability. Cost considerations include the initial higher capital cost of alternative solutions, operating and maintenance costs, and any associated training and productivity costs.

\section{Non-EPAct Government and Institutional Fleets}

Non-EPAct government and institutional fleets account for about $10 \%$ of the fleet market. The drivers and barriers that impact this group differ from those of the corporate

\footnotetext{
${ }^{114}$ K. Nesbitt and D. Sperling, 2001. Fleet purchasing behavior: decision processes and implications for new vehicle technologies and fuels.

115 Ibid

116 Automotive Fleet Fact Book, Edition 24, 2004. As a point of interest, Wal-Mart is No. 30 on the list w/ 3,703 total fleet vehicles (6\% are heavy duty, Class 3-6). Wal-Mart likely contracts out most of its trucking.

${ }^{117}$ K. Nesbitt and D. Sperling, 2001. Fleet purchasing behavior: decision processes and implications for new vehicle technologies and fuels.
} 
fleet, primarily because of organizational structure. ${ }^{118}$ Non-EPAct and institutional fleets tend to follow company policy and favor the status quo. Fleet policies are often established centrally and administered locally. ${ }^{119}$

Market barriers in this group reflect the highly formalized, decentralized structure of these organizations. Non-EPAct and institutional fleet purchasing decisions may rely on precedent and can be veto-prone. This category of fleet manager tends to be more reactive and favor short-term solutions in their purchasing patterns. ${ }^{120}$

\footnotetext{
${ }^{118}$ K. Nesbitt and D. Sperling, 2001. Fleet purchasing behavior: decision processes and implications for new vehicle technologies and fuels.

${ }^{119} \mathrm{Ibid}$

${ }^{120}$ Ibid
} 


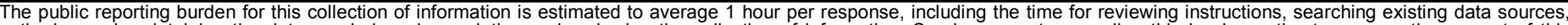

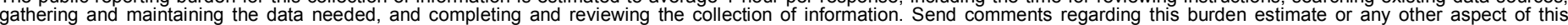

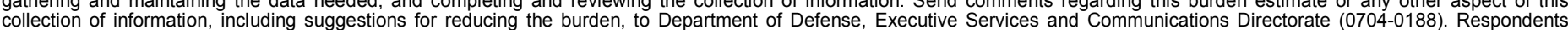

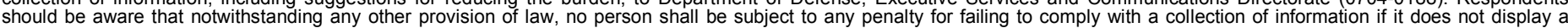

shrrently valid OMB control number.

PLEASE DO NOT RETURN YOUR FORM TO THE ABOVE ORGANIZATION.

\begin{tabular}{l|l|l|l} 
1. REPORT DATE $(D D-M M-Y Y Y Y)$ & 2. REPORT TYPE & 3. DATES COVERED (FrOm - TO)
\end{tabular}

October 2006

Technical Report

4. TITLE AND SUBTITLE

Energy Sector Market Analysis

5a. CONTRACT NUMBER

DE-AC36-99-G010337

5b. GRANT NUMBER

5c. PROGRAM ELEMENT NUMBER

6. AUTHOR(S)

D. Arent, R. Benioff, G. Mosey, L. Bird, J. Brown, E. Brown,

L. Vimmerstedt, J. Aabakken, K. Parks, M. Lapsa, S. Davis,

M. Olszewski, D. Cox, K. McElhaney, S. Hadley, D. Hostick,

A. Nicholls, S. McDonald, and B. Holloman

5d. PROJECT NUMBER

NREL/TP-620-40541

5e. TASK NUMBER

IGST.5000

5f. WORK UNIT NUMBER
7. PERFORMING ORGANIZATION NAME(S) AND ADDRESS(ES)

National Renewable Energy Laboratory

1617 Cole Blvd.

Golden, CO 80401-3393

9. SPONSORING/MONITORING AGENCY NAME(S) AND ADDRESS(ES)
8. PERFORMING ORGANIZATION REPORT NUMBER

NREL/TP-620-40541
10. SPONSOR/MONITOR'S ACRONYM(S) NREL

11. SPONSORING/MONITORING AGENCY REPORT NUMBER

12. DISTRIBUTION AVAILABILITY STATEMENT

National Technical Information Service

U.S. Department of Commerce

5285 Port Royal Road

Springfield, VA 22161

13. SUPPLEMENTARY NOTES

14. ABSTRACT (Maximum 200 Words)

This paper presents the results of energy market analysis sponsored by the Department of Energy's (DOE)

Weatherization and Intergovernmental Program (WIP) within the Office of Energy Efficiency and Renewable Energy

(EERE). The analysis was conducted by a team of DOE laboratory experts from the National Renewable Energy

Laboratory (NREL), Oak Ridge National Laboratory (ORNL), and Pacific Northwest National Laboratory (PNNL), with additional input from Lawrence Berkeley National Laboratory (LBNL). The analysis was structured to identify those markets and niches where government can create the biggest impact by informing management decisions in the private and public sectors. The analysis identifies those markets and niches where opportunities exist for increasing energy efficiency and renewable energy use.

15. SUBJECT TERMS

markets; market barriers; market drivers; clean energy sector; buildings sector; industrial sector; transportation sector; sector characteristics; National Renewable Energy Laboratory; NREL; Oak Ridge National Laboratory; ORNL; Pacific Northwest National Laboratory; PNNL

\begin{tabular}{|c|c|c|c|c|c|}
\hline 16. SECURITY & CLASSIFICATI & N OF: & 17. LIMITATION & 18. NUMBER & 19a. NAME OF RESPONSIBLE PERSON \\
\hline a. REPORT & b. ABSTRACT & c. THIS PAGE & OF ABSIRACI & & \\
\hline Unclassified & Unclassified & Unclassified & & & 19b. TELEPHONE NUMBER (Include area code) \\
\hline
\end{tabular}

